\title{
Original paper \\ Petrologic comparison of the Gyód and Helesfa serpentinite bodies (Tisia Mega Unit, SW Hungary)
}

\author{
Gábor KOVÁCS', Balázs Géza RADOVICS², Tivadar M. TÓTH* \\ ${ }^{1}$ Hungarian Office for Mining and Geology, Mining District Authority of Veszprém, Megyeház tér 1., 8200 Veszprém, Hungary \\ ${ }^{2}$ MOL Hungarian Oil and Gas Public Limited Company, Október huszonharmadika u. 18, 1117 Budapest, Hungary \\ ${ }^{3}$ University of Szeged, Department of Mineralogy, Geochemistry and Petrology, Egyetem utca 2. 6722 Szeged, Hungary; \\ mtoth@geo.u-szeged.hu \\ *Corresponding author
}

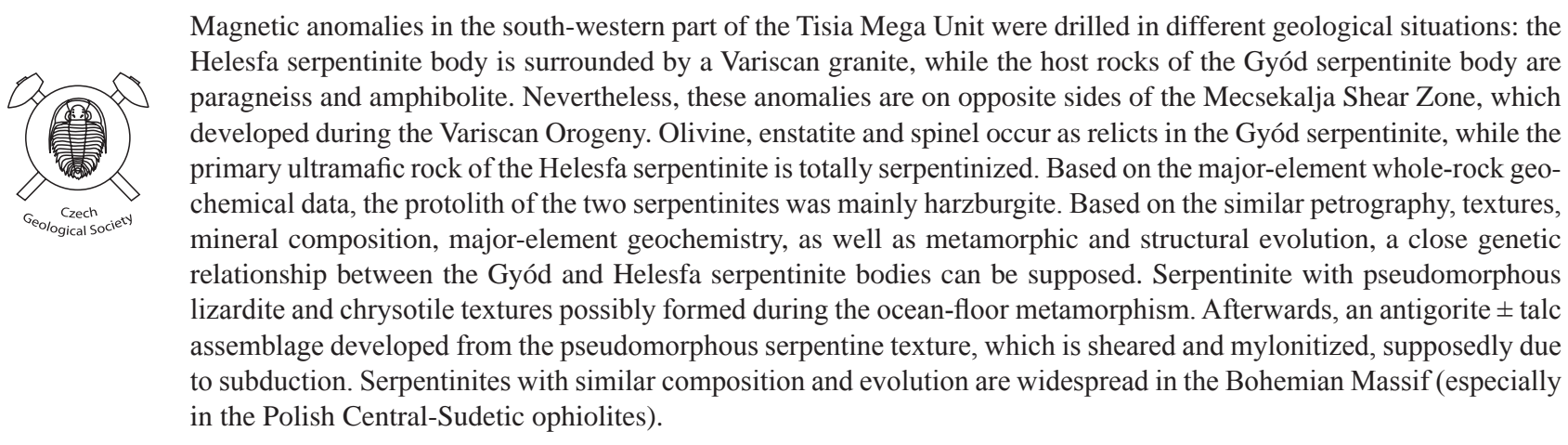

Keywords: serpentinite, harzburgite, websterite, Alpine-type ophiolite, Tisia, Variscides

Received: 5 March, 2016; accepted: 30 September, 2016; handling editor: E. Jelinek

\section{Introduction}

The results from seismic studies and ocean drilling revealed that large volumes of serpentinized mantle occur at passive continental margins (Boillot et al. 1989, 1992) and slow spreading ridges (Cannat et al. 1995). The abundance of serpentinites in oceanic lithosphere and highpressure meta-ophiolites from orogenic belts suggests that these rocks can play an important role in subduction and exhumation processes (e.g., Hermann et al. 2000).

Serpentinite bodies are of great help in the specification of the geodynamic settings of the Variscan and Alpine orogenies. Serpentinites are known from numerous pre-Mesozoic areas, such as the Bohemian Massif (e.g. Höck et al. 1997; Gunia et al. 1998; Medaris et al. 2005) and Mesozoic Alpine complexes (e.g. Melcher et al. 2002). Field studies demonstrated that serpentine minerals (firstly lizardite, chrysotile and antigorite) are the major constituents of the metamorphosed ultramafic rocks in the Alpine ophiolites (Trommsdorff and Evans 1974; Piccardo et al. 1980; Lemoine et al. 1987; Lagabrielle and Cannat 1990).

Detailed geophysical measurements started in SW Hungary in the 1960s in connection with uranium ore exploration in the Mecsek Mountains. Based on the land magnetic, aeromagnetic and aero-gamma surveys, small local anomalies were recorded, which were drilled by exploration boreholes in some cases. In this way, the Gyód serpentinite (GS) and Helesfa serpentinite (HS) bodies were recognized in the crystalline basement of SW Tisia Mega Unit (Fülöp 1994). During geological exploration, a third, Ófalu serpentinite body (OS) was identified (Ghoneim and Ravasz-Baranyai 1969).

The early petrographic and geochemical analyses (Ghoneim and Ravasz-Baranyai 1969; Erdélyi 1974; Szederkényi 1974, 1976b, 1977; Szederkényi and Grasselly 1977; Ghoneim 1978; Jantsky 1979; Ghoneim and Szederkényi 1979; Svingor and Kovách 1981; Balla 1981, 1983, 1985; Papp 1989) led to different opinions regarding the protoliths, metamorphic evolution and genesis of the two serpentinite bodies. Petrographic, mineralogical and geochemical comparison of the Gyód and Helesfa serpentinites, based on the available drill cores, is presented in this work. A detailed evaluation of the likely protoliths, metamorphic evolution as well as deformation history of both bodies may serve as a firm basis to delineate a uniform evolution scheme for the study area. In the future, this approach would provide data for comparisons with other serpentinite bodies in the vicinity and thus the Tisia Mega Unit’s evolution. 


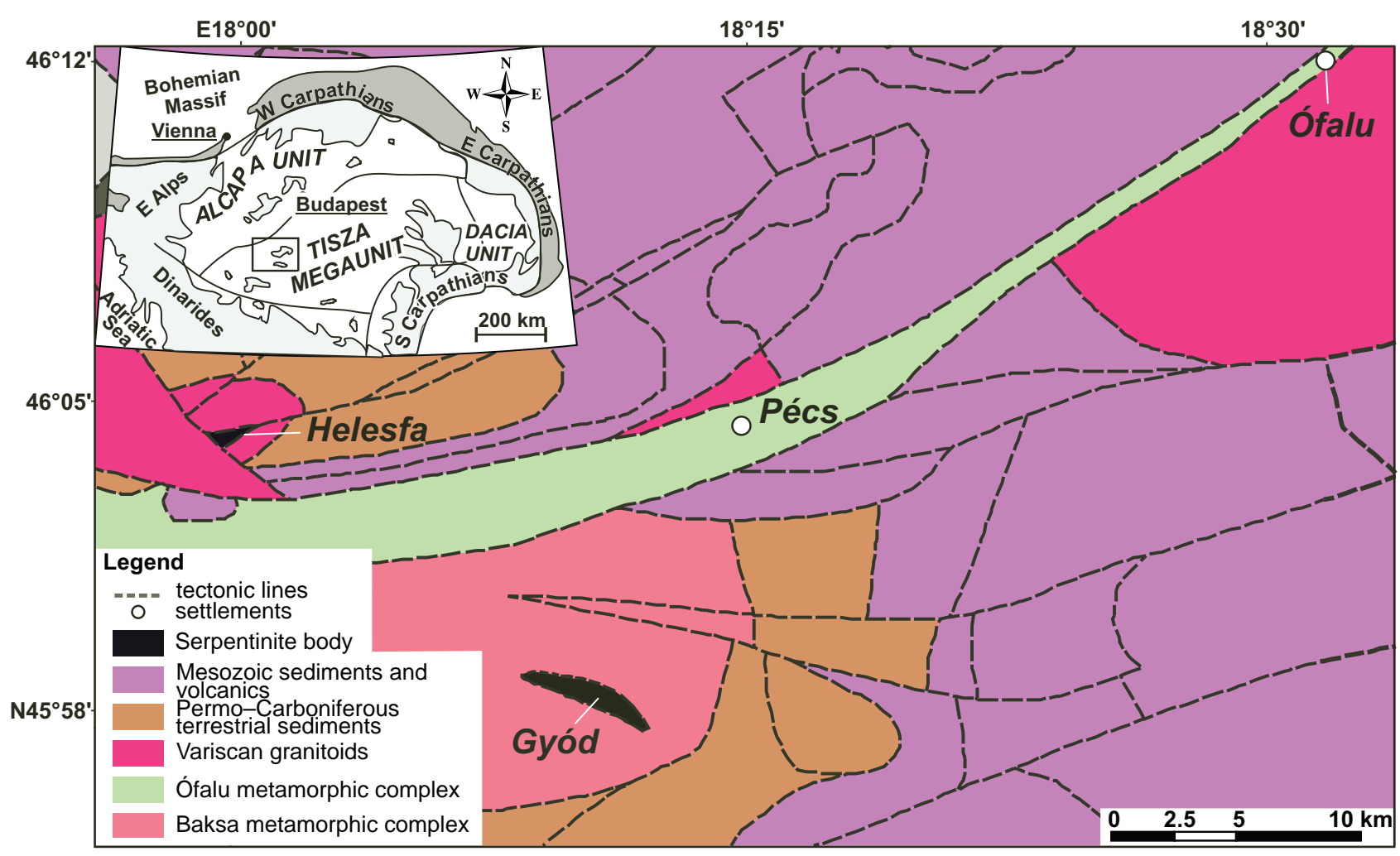

Fig. 1 The Pre-Neogene geological map of south-western part of the Tisia Mega Unit (SW Hungary) and position of the Gyód and Helesfa serpentinite bodies (Fülöp 1994). Inset: sketch map of the Pannonian Basin and its surroundings. The framed area is enlarged.

\section{Geological setting}

\subsection{Tisia Megaunit}

The large, microcontinent-sized Tisia Mega Unit forms a single Alpine terrane in the SE part of the Pannonian domain which represents the European margin of the Tethys. It was incorporated into its present location by horizontal microplate displacement during the Alpine Orogeny (e.g. Csontos et al. 1992). The Permian-Mesozoic sediments cover the older crystalline rocks which crop out only in isolated inselbergs in NE Croatia and SW Hungary, but to a much larger extent in the Apuseni Mts. of Romania. Its Alpine metamorphic zones were superimposed on Variscan metamorphic zones and show a good correlation with those recognized in different Tethyan realms (Haas et al. 1995 and references therein). For instance, the Mecsek Zone was possibly once a continuation of the Variscan Moldanubian Zone (Buda et al. 2004; Klötzli et al. 2004), whereas the more southerly zones formed a continuation of the Mediterranean Crystalline Zone.

The Triassic Tisia Mega Unit belonged to the northern (European) margin of Neotethys, from where it became separated in the Middle Jurassic due to the beginning of Penninic rifting. From that time onward it existed as a large, independent terrane until the Early Miocene. It reached its present position after various rotations only by the end of the Early Miocene (Csontos et al. 1992; Márton 2000).

There are still many open questions concerning the relationships between the underlying crystalline rocks of the European Variscan Belt and those of the Tisia plate. According to Szederkényi (1996), eclogite samples on the NE and on the SW part of the Tisia Mega Unit represent a SW-NE trending suture zone of an ancient Variscan ocean. Szederkényi (1996) suggested a possible geological relationship between the low-grade Silurian black shales in the SW part of the Tisia and those in the Moravicum. If true, the Tisia should represent a composite segment of diverse tectonic realms of the European Variscan Belt.

\subsection{Host-rocks of the studied ultramafic bodies}

The Gyód serpentinite body is wedged into Variscan, medium-grade metamorphic rocks of the Baksa Complex (Szederkényi 1998; Konrád et al. 2010) while the Helesfa serpentinite body occurs in Variscan granites. The smallest serpentinite lens at Ófalu is located within the Mecsekalja Shear Zone (corresponding with Ófalu Metamorphic Complex) on the surface (Fig. 1).

Medium-grade metamorphic rocks, i.e. gneisses, mica schists, amphibolites and calc-silicate rocks (Szederkényi 
1979, 1984, 1996; M. Tóth 2014) play an important role in the geological construction of the crystalline basement of the Baksa Complex (Fig. 1). The metamorphic rocks underwent Barrovian-type, amphibolite-facies regional metamorphism (Szederkényi 1976a, 1979) followed by a low-pressure Variscan overprint. The latter was closely related with the granitoid magmatism, and the metamorphic grade passed from lower greenschist- to amphibolite-facies conditions (Árkai 1984).

Nevertheless, some eclogite-facies rock samples appear as well, which is inconsistent with the above metamorphic evolution; Ravasz-Baranyai (1969) was the first to identify eclogite in the Görcsöny-1 borehole. In the nearby Gyód-2 borehole, Pliocene basal conglomerates, deposited onto the GS, contain eclogite pebbles (Horváth et al. 2003). High-pressure metamorphism was proven by an analysis of the garnet gneiss and amphibolite in the deepest part of the Baksa-2 borehole (Nagy and M. Tóth 2009; M. Tóth 2014).

Variscan syn-collisional granitoid rocks are widespread in the Tisia Mega Unit (Buda 1981, 1985). The geochronological study of the Mórágy Granite (Fig. 1) has been carried out for the last four decades. The results obtained are mostly $\mathrm{K}-\mathrm{Ar}, \mathrm{Rb}-\mathrm{Sr}$ and $\mathrm{Pb}-\mathrm{Pb}$ data on the rock-forming minerals (biotite, amphibole, potassium feldspar) and whole-rock samples; there are only several $\mathrm{U}-\mathrm{Pb}$ and $\mathrm{Pb}-\mathrm{Pb}$ age determinations on zircons (Árva-Sós and Balogh 1979; Svingor and Kovách 1981; Balogh et al. 1983; Buda 1985; Buda et al. 1999; Klötzli et al. 2004). The geochronological data scatter in an interval of 300-370 Ma depending on different age dating methods. The likely intrusive age of the granite was probably close to $354 \pm 5 \mathrm{Ma}(\mathrm{Pb}-\mathrm{Pb}$ zircon age of Klötzli et al. 2004).

Additionally, low-grade metamorphic rocks (Ófalu Fm.) occur with obscure structural connections to all previous complexes (Fig. 1).

\subsection{Gyód and Helesfa serpentinite bodies}

\subsubsection{Gyód serpentinite (GS)}

The GS body is $5-7 \mathrm{~km}$ long and $200-500 \mathrm{~m}$ wide; it is nearly vertical with a WNW-ESE strike. The geometric centre of the magnetic anomaly is at approximately 400 $m$ depth (Géresi et al. 1971). According to the same authors, the pinching out depth is unknown but should not exceed $700-800 \mathrm{~m}$. The serpentinite body is covered by $\sim 65 \mathrm{~m}$ thick Pliocene and Pleistocene sediments. The GS was penetrated in a $56 \mathrm{~m}$ section along the geometric centre of the serpentinized body by the Gyód-2 drilling. The Gyód-3 and Gyód-4 drillings sampled host rocks with continuous coring.

\subsubsection{Helesfa serpentinite (HS)}

The HS body has an ENE-WSW strike and $65-70^{\circ}$ SSE tilt along a 5-6 km length and has a contact with cataclastic-mylonitic granite along an approximately $20 \mathrm{~m}$ wide talc schist zone consisting of talc, lizardite, dolomite, magnesite and chlorite (Fülöp 1994; Rónaky 1996). Geophysical data prove that the HS pinches out in the deeper zone.

\subsection{3. Ófalu serpentinite (OS)}

The OS body is nearly vertical, approximately $10 \mathrm{~m}$ thick, and bordered by low-grade rocks along tectonic zones. It is located at the surface, in the central part of Goldgrund Valley in the Mecsekalja Shear Zone (Ófalu metamorphic complex) (Fig. 1).

\section{Methods}

\subsection{Sampling}

In total, $\sim 180$ samples were obtained from the available cores from the Gyód-2 and Helesfa-1 boreholes. The samples from Gyód-2 borehole are representative because the drilling in the GS body was sampled over a $0.5-1 \mathrm{~m}$ interval in the $65.2-131.5 \mathrm{~m}$ range. Approximately 160 oriented thin sections were prepared.

The Helesfa-1 borehole (total depth: $650 \mathrm{~m}$ ), which explored the HS body, was sampled periodically (63 cores). During the drilling, a $290.95 \mathrm{~m}$ core was obtained, of which only a fraction has survived. Based on the original documentation of Helesfa-1, 99 pieces of them were drilled; our research consists of 48 pieces of cores, which sampled different sections of the borehole. Fifteen thin sections were prepared from the macroscopically described rock types in the HS body.

\subsection{Raman spectrometry}

In recent decades many studies have been published about the accurate identification of serpentine minerals by Raman spectrometry (Kloprogge et al. 1999; Rinaudo et al. 2003; Groppo et al. 2006).

The samples were analysed by a Thermo Scientific DXR Raman microscope at the Department of Mineralogy, Geochemistry and Petrology at the University of Szeged. In addition to single point measurements, Raman mappings yielded the spatial distributions of mineral phases. The analytical conditions were a 532 $\mathrm{nm}$ (green) wavelength, high-resolution optical grid and $10 \mathrm{~mW}$ laser power; the data acquisition was in the 
range of $50-1200 \mathrm{~cm}^{-1}$. The exposure time varied from 3 to $10 \mathrm{~min}$. The analyses were carried out with $50 \times$ and $100 \times$ objectives. The sizes of the grid cells were $6-10$ $\mu \mathrm{m}$, the exposure of every point was $1 \mathrm{~min}$, and a $50 \times$ objective was used.

\subsection{Whole-rock geochemistry}

From the Gyód-2 borehole, 19 samples were analysed for their whole-rock geochemical composition. X-ray fluorescence (XRF) analyses were carried out at the University of Pannonia, Veszprém. Five samples were analysed using Philips PW2404 X-ray fluorescence spectrometer, incident X-ray beam is typically produced from a $4 \mathrm{~kW}$ $\mathrm{Rh}$ target in vacuum, detectors: flow, scintillation, duplex, collimators: 27 and $37 \mathrm{~mm}$.

Furthermore analyses of five samples were carried out in X-Ray Assay Laboratories (XRAL) at the University of Toronto. Determinations on 9 samples were obtained using the JY-70 ICP-OES hosted in the laboratory of the Geological Institute of Hungary in Budapest. Samples were dissolved following lithium metaborate $\left(\mathrm{LiBO}_{2}\right)$ fusion and taken into $\mathrm{HCl}$ solution, using a ten-fold dilution for $0.2 \mathrm{~g}$ of sample. The analytical conditions were: RF power $1000 \mathrm{~W}$, reflected energy $<10 \mathrm{~W}$, plasma gas flow rate of $12 \mathrm{l} / \mathrm{min}$, sheath gas flow rate $0, .21 / \mathrm{min}$, spray type of cross-flow, atomizer gas flow rate $0.4 \mathrm{l} / \mathrm{min}$, pressure $2.7 \mathrm{bar}$, observation height $15 \mathrm{~mm}$, integration time $0.5 \mathrm{~s}$ (poly) $-5 \mathrm{~s}$ (mono).

Ten samples were analysed from the Helesfa-1 borehole. The measurements were carried out by the RIGAKU Supermini WDS XRF at the Department of Mineralogy, Geochemistry and Petrology at the University of Szeged. For the analyses pressed powder pellets were made with $\mathrm{Li}_{2} \mathrm{~B}_{4} \mathrm{O}_{7}$. The Pd X-ray source, $50 \mathrm{kV}$ excitation voltage and $4 \mathrm{~mA}$ anode current were used for the measurements. International standards (DC70305, DC70306, DC70308, DC70309, DC70310, DC70312, DC70314, DC70318, DC71305, and NIM-D Dunite) were applied for the standardization.

\subsection{Mineral chemistry}

Chemical analyses of minerals were carried out by a JEOL JXCA-733 electron microprobe (EMP) equipped with three WDS detectors in the Laboratory for Geochemical Research, Hungarian Academy of Sciences, Budapest. The measuring conditions were: $15 \mathrm{kV}$ acceleration voltage; $40 \mathrm{nA}$ sample current; electron beam with a diameter of $5 \mu \mathrm{m}$ and $5 \mathrm{~s}$ counting time.

Further EMP analyses were performed in the Laboratory of Toronto University using CAMECA SX50 electron microprobe. Operating conditions were $15 \mathrm{keV}$ accelerating voltage, $30 \mathrm{nA}$ sample current, 40 take-off angle degree, electron beam with a diameter of $5 \mu \mathrm{m}$ and $5 \mathrm{~s}$ counting time.

Matrix effects were corrected by using the ZAF method. The following standards were used for quantitative analysis: orthoclase $(\mathrm{K}, \mathrm{Al}, \mathrm{Si})$, synthetic glass $(\mathrm{Fe}, \mathrm{Mg}$, $\mathrm{Ca})$, spessartine $(\mathrm{Mn})$, rutile (Ti) and albite $(\mathrm{Na})$. Mineral chemistry data were calculated by MINPROG computer program written by Sz. Harangi (Eötvös University, Budapest). For spinel $\mathrm{Fe}^{2+}-\mathrm{Fe}^{3+}$ calculation Droop's equation (1987) was used. The mineral abbreviations used are after Kretz (1983).

\subsection{P-T calculations}

The $P-T$ metamorphic conditions were calculated using the THERIAK-Domino program (de Capitani and Brown 1987; de Capitani 1994, 2010). Domino is particularly useful in analysing relict parageneses because it computes the complete, stable assemblage at each stage of a given $P-T$ evolution. The data from both the GS and the HS can be discussed in the same model because they record identical evolution steps. The input data of the model were the molar bulk rock compositions $(\mathrm{Si}, \mathrm{Al}$, $\mathrm{Fe}, \mathrm{Mg}, \mathrm{Ca}$, and $\mathrm{H}$ system) of some GS and HS samples. We assumed ideal solid solutions for olivine (forsteritefayalite), orthopyroxene (enstatite-ferrosilite), spinel (spinel-hercynite) and clinopyroxene (diopside-hedenbergite). The thermodynamic data come from Berman's (Berman 1988) database.

\section{Results}

\subsection{Petrohraphy}

\subsubsection{Gyód serpentinite}

Based on the macroscopic examination, the rock body if formed mainly of dark-green to dark-grey, massive, homogeneous, fine-grained serpentinite. Less commonly, light-grey or whitish, coarser grained domains of lenticular shapes occur that are formed by olivine and pyroxene. Based on the metamorphic textures, four serpentinite types can be distinguished (Kovács 2000): ultramaficsbearing serpentinite, typical serpentinite, bastite-type serpentinite and sheared serpentinite.

The texture of the GS body's protolith was mostly porphyroclastic (Mercier and Nicolas 1975); in places with protogranular enstatite domains (Kovács et al. 2003). According to the mineral composition and textural relics, the protolith was not uniform; olivine- and a pyroxene-rich domains can be defined (Kovács et al. 2009) (Fig. 2a). Relict olivine porphyroblasts $\left(\mathrm{Fo}_{90.4-91.4}\right)$ (Tab. 1) are generally xenomorphic; they have elongated 

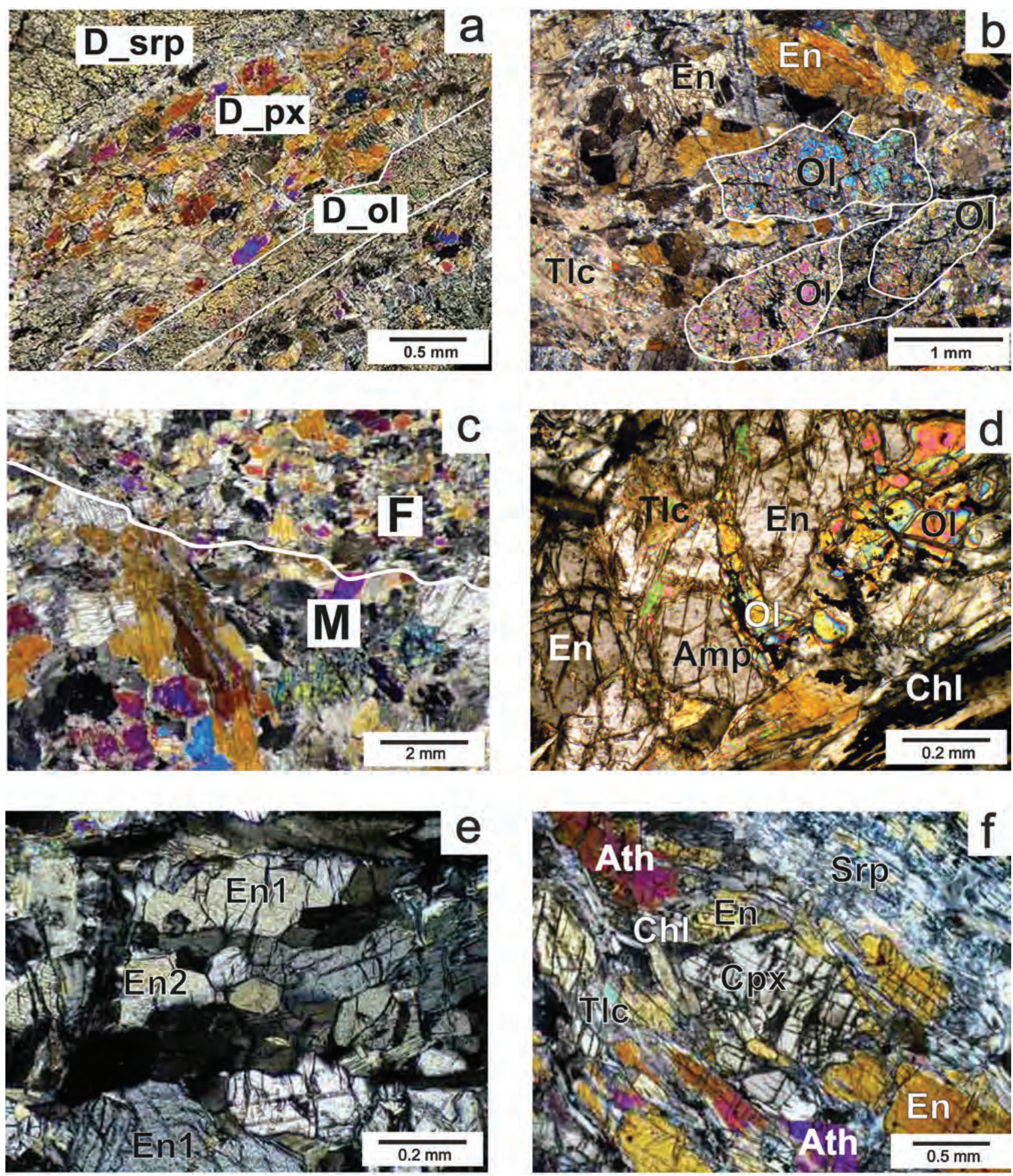

Fig. 2 The ultramafic domains (D) of the Gyód serpentinite. a - Serpentinite domain (D srp), parallel bands of pyroxene (D px) and olivine-bearing (D ol) domains (XPL). b - Medium-grained, deformed olivine porphyroblasts in the relict ultramafic domain. The opaque lines represent the initial serpentinization (XPL). c - Medium- (M) and fine-grained (F) pyroxene-bearing ultramafic domain (XPL). d - Amoeboid olivine grains in the interstitial texture of the pyroxene domain (XPL). e - Rounded, recrystallized polygonal enstatite (En2) among the hypidiomorphic enstatite grains (En1) (XPL). $\mathbf{f}$ - Clinoenstatite surrounded by enstatite and anthophyllite, aligned parallel to the foliation (XPL).

or oval shapes (Fig. 2b) with an average size of 1-4 mm. In addition to olivine, pyroxene is the most common relict mineral. Based on their optical characteristics, both ortho- and clinopyroxenes can be distinguished; 
Table 1 Representative analyses of primary olivine from the Gyód serpentinite (wt. \% and apfu calculated on the basis of $4 \mathrm{O}$ )

\begin{tabular}{|c|c|c|c|c|c|c|c|c|c|}
\hline \multirow{2}{*}{$\begin{array}{l}\text { No. } \\
\text { wt. \% }\end{array}$} & \multicolumn{3}{|c|}{7083} & \multirow{2}{*}{$\begin{array}{c}7083 \mathrm{~B} \\
\mathrm{o} 44\end{array}$} & \multicolumn{2}{|c|}{7084} & \multicolumn{2}{|c|}{7006} & \multirow{2}{*}{$\begin{array}{l}7006-1 \\
\text { ol9_is }\end{array}$} \\
\hline & ol1 & $\mathrm{ol} 2 \_\mathrm{pb}$ & $\mathrm{ol3}$ & & ol5 & ol6 & $\mathrm{ol}$ _pb & ol8 & \\
\hline $\mathrm{SiO}_{2}$ & 38.79 & 41.32 & 38.63 & 38.65 & 38.65 & 38.45 & 40.94 & 40.68 & 40.85 \\
\hline $\mathrm{Al}_{2} \mathrm{O}_{3}$ & - & - & - & - & - & - & - & - & 0.01 \\
\hline $\mathrm{FeO}$ & 9.36 & 9.00 & 8.87 & 9.50 & 9.50 & 9.30 & 9.02 & 8.39 & 9.02 \\
\hline $\mathrm{NiO}$ & 0.61 & 0.45 & 0.80 & 0.66 & 0.66 & 0.12 & 0.00 & 0.39 & 0.54 \\
\hline $\mathrm{MgO}$ & 50.94 & 48.60 & 51.18 & 50.91 & 50.91 & 50.92 & 50.92 & 49.85 & 49.24 \\
\hline Total & 99.70 & 99.37 & 99.62 & 100.12 & 100.12 & 99.23 & 100.88 & 99.31 & 99.83 \\
\hline $\mathrm{Si}$ & 0.96 & 1.01 & 0.96 & 0.96 & 0.96 & 0.96 & 0.99 & 1.00 & 1.00 \\
\hline Al & - & - & - & - & - & - & - & - & 0.00 \\
\hline $\mathrm{Fe}$ & 0.19 & 0.19 & 0.18 & 0.20 & 0.20 & 0.19 & 0.18 & 0.17 & 0.19 \\
\hline $\mathrm{Ni}$ & 0.01 & 0.01 & 0.02 & 0.01 & 0.01 & 0.00 & 0.00 & 0.01 & 0.00 \\
\hline $\mathrm{Mg}$ & 1.88 & 1.78 & 1.89 & 1.88 & 1.88 & 1.89 & 1.84 & 1.82 & 1.80 \\
\hline Total & 3.04 & 1.21 & 3.04 & 3.04 & 3.04 & 3.04 & 1.17 & 1.18 & 3.01 \\
\hline Fo & 90.65 & 90.58 & 91.14 & 90.52 & 90.52 & 90.71 & 90.94 & 91.38 & 90.57 \\
\hline $\mathrm{Fa}$ & 9.35 & 9.42 & 8.86 & 9.48 & 9.48 & 9.29 & 9.06 & 8.62 & 9.31 \\
\hline Mg\# & 90.65 & 90.58 & 91.14 & 90.52 & 90.52 & 90.71 & 90.94 & 91.38 & 90.68 \\
\hline
\end{tabular}

is = interstitial, $\mathrm{pb}=$ porphyroblast

$\mathrm{Mg} \#=100 \times \mathrm{Mg} /(\mathrm{Mg}+\mathrm{Fe})$

Table 2 Representative analyses of enstatite from the Gyód serpentinite (wt. \% and apfu calculated on the basis of $6 \mathrm{O}$ )

\begin{tabular}{|c|c|c|c|c|c|c|c|}
\hline \multirow{2}{*}{$\begin{array}{l}\text { No. } \\
\text { wt. \% }\end{array}$} & \multicolumn{4}{|c|}{7083} & \multicolumn{3}{|c|}{ 7006-1 } \\
\hline & opx1_c & opx2_r & opx3_c & opx4_r & opx5_r & opx6 & opx7 \\
\hline $\mathrm{SiO}_{2}$ & 57.54 & 57.13 & 57.63 & 57.42 & 57.82 & 58.05 & 57.74 \\
\hline $\mathrm{TiO}_{2}$ & 0.02 & 0.04 & 0.00 & 0.03 & 0.02 & 0.01 & 0.02 \\
\hline $\mathrm{Al}_{2} \mathrm{O}_{3}$ & 0.14 & 0.26 & 0.06 & 0.05 & 0.04 & 0.04 & 0.09 \\
\hline $\mathrm{Cr}_{2} \mathrm{O}_{3}$ & 0.06 & 0.04 & 0.07 & 0.02 & 0.03 & 0.02 & 0.01 \\
\hline $\mathrm{FeO}$ & 6.18 & 6.59 & 6.40 & 6.32 & 6.31 & 6.14 & 6.14 \\
\hline $\mathrm{MnO}$ & 0.15 & 0.16 & 0.12 & 0.15 & 0.08 & 0.11 & 0.12 \\
\hline $\mathrm{MgO}$ & 34.92 & 34.66 & 34.85 & 34.96 & 35.21 & 35.23 & 35.12 \\
\hline $\mathrm{CaO}$ & 0.06 & 0.07 & 0.06 & 0.04 & 0.07 & 0.11 & 0.07 \\
\hline $\mathrm{Na}_{2} \mathrm{O}$ & 0.00 & 0.02 & 0.00 & 0.01 & 0.00 & 0.01 & 0.03 \\
\hline $\mathrm{K}_{2} \mathrm{O}$ & 0.00 & 0.00 & 0.00 & 0.00 & 0.01 & 0.00 & 0.00 \\
\hline $\mathrm{NiO}$ & 0.13 & 0.11 & 0.15 & 0.06 & 0.13 & 0.07 & 0.15 \\
\hline Total & 99.21 & 99.09 & 99.35 & 99.06 & 99.73 & 99.79 & 99.48 \\
\hline $\mathrm{Si}$ & 1.997 & 1.990 & 2.000 & 1.996 & 1.997 & 2.000 & 1.998 \\
\hline $\mathrm{Al}$ & 0.003 & 0.010 & 0.000 & 0.002 & 0.002 & 0.000 & 0.002 \\
\hline $\mathrm{Al}$ & 0.003 & 0.001 & 0.002 & 0.000 & 0.000 & 0.003 & 0.002 \\
\hline $\mathrm{Fe}(\mathrm{III})$ & 0.000 & 0.011 & 0.000 & 0.006 & 0.003 & 0.000 & 0.001 \\
\hline $\mathrm{Cr}$ & 0.002 & 0.001 & 0.002 & 0.000 & 0.001 & 0.001 & 0.000 \\
\hline $\mathrm{Ti}$ & 0.001 & 0.001 & 0.000 & 0.001 & 0.001 & 0.000 & 0.000 \\
\hline $\mathrm{Fe}(\mathrm{II})$ & 0.179 & 0.180 & 0.186 & 0.178 & 0.179 & 0.177 & 0.177 \\
\hline Mn & 0.004 & 0.005 & 0.004 & 0.004 & 0.002 & 0.003 & 0.004 \\
\hline $\mathrm{Mg}$ & 1.807 & 1.800 & 1.803 & 1.812 & 1.813 & 1.810 & 1.812 \\
\hline $\mathrm{Ca}$ & 0.002 & 0.003 & 0.002 & 0.001 & 0.002 & 0.004 & 0.003 \\
\hline $\mathrm{Na}$ & 0.000 & 0.002 & 0.000 & 0.001 & 0.000 & 0.001 & 0.002 \\
\hline $\mathrm{K}$ & 0.000 & 0.000 & 0.000 & 0.000 & 0.000 & 0.000 & 0.000 \\
\hline Total & 3.999 & 4.004 & 3.998 & 4.002 & 4.001 & 3.998 & 4.000 \\
\hline Wo & 0.12 & 0.13 & 0.11 & 0.07 & 0.12 & 0.20 & 0.13 \\
\hline En & 90.66 & 89.98 & 90.39 & 90.51 & 90.65 & 90.75 & 90.70 \\
\hline Fs & 9.21 & 9.82 & 9.50 & 9.39 & 9.23 & 9.03 & 9.07 \\
\hline Ac & 0.02 & 0.08 & 0.00 & 0.03 & 0.00 & 0.03 & 0.09 \\
\hline $\mathrm{Fe}^{\mathrm{II}} /\left(\mathrm{Fe}^{\mathrm{II}}+\mathrm{Fe}^{\mathrm{III}}\right)$ & 1.02 & 0.94 & 1.03 & 0.97 & 0.98 & 1.03 & 0.99 \\
\hline Mg\# & 90.97 & 90.38 & 90.66 & 90.80 & 90.87 & 91.09 & 91.07 \\
\hline
\end{tabular}

$\mathrm{c}=$ centre, $\mathrm{r}=$ rim of the grain

$\mathrm{Mg} \#=100 \times \mathrm{Mg} /(\mathrm{Mg}+\mathrm{Fe})$ the orthorhombic variety is the more common one. Enstatite grains $\left(\mathrm{En}_{88.1-92.3}\right)($ Tab. 2) are usually hypidiomorphic, columnar, with an average size of 1-3 $\mathrm{mm}$. Occasionally, even over $1 \mathrm{~cm}$-long, elongated grains occur (Kovács et al. 2003). The smaller clinoenstatite crystals are commonly xenomorphic, round and resorbed, and are generally surrounded by orthoenstatite (Fig. 2c). Cr-spinel (with diverse $\mathrm{Mg}, \mathrm{Al}, \mathrm{Fe}$ contents; Tab. 3) and pentlandite are the main opaque minerals in the ultramafic relics.

In addition to the olivine porphyroblasts, a $0.5-1 \mathrm{~mm}$ sized, xenomorphic, interstitial forsterite generation (Tab. 1) appears, penetrating the inlets of enstatite crystals (Fig. 2d). Medium-grained enstatite porphyroclasts have undulose extinction, contain microfractures and are sheared in places. Small $(0.1-0.5 \mathrm{~mm})$ enstatite crystals occur along the edges of the enstatite porphyroclasts. The small, isometric grains meet along Y-shaped boundaries and have wavy extinction (Fig. 2e). The enstatite porphyroclasts are surrounded by tiny $(\sim 0.1 \mathrm{~mm})$ neoblasts (Fig. 2e) with isometric, mainly xenomorphic forms that meet along Y-shaped rounded grain boundaries; cleavage is rarer than in bigger grains. Enstatite crystals, $0.05-0.1 \mathrm{~mm}$ across, appear in relict domains (Fig. $2 \mathrm{f}$ ). These relict domains contain anthophyllite crystals, whose contacts with resorbed enstatite are often bordered by talc, chlorite and serpentine (Fig. 2f). In places, tremolite with an average size of $0.5-1$ $\mathrm{mm}$ also coexists with enstatite in the pyroxene domains.

Chlorite is a common phase in both the relict protolith and 
serpentinite. Chlorite bundles flow around pyroxene-rich domains, while chlorite is much rarer in the olivine-bearing parts. The size of the chlorite flakes varies from 0.1 to $\sim 2$ $\mathrm{mm}$; in cases, larger grains are curved and wavy. The chlorites are optically zoned, and kinkbands occur in places.

The typical serpentinite is the most characteristic rock type of the samples; it is a dark-grey, massive, very fine-grained rock that basically consists of tiny serpentine and chlorite crystals. In the GS body, pseudomorphous textures of different transformation stages also occur, indicating the partial hydration of olivine.

The alteration of olivine grains is usually gradual, starting at the rims and progressing towards the centres along fractures. Polygonal cells form the basis of the mesh texture, where the total alteration of olivine is not typical; its relics regularly appear in the centre of the cells. In this way, fibrous serpentine crystals first developed at the rim and magnetite crystals in the central fractures (Fig. 3a). In those places where the serpentinization grade was higher, the olivine crystals (Fig. 4a) in the mesh centre transformed entirely into serpentine minerals and magnetite crystals along the central parting. Based on Raman spectroscopy, the serpentine crystals in both the mesh centres and rims are lizardite (Fig. 4b) despite their different microtextures.

The name "bastite-type serpentinite" originated from serpentine pseudomorphs replacing relict minerals (bastites, Haidinger 1845). Bastites have a silky, olive green colour, columnar shape and, in cases, are elongated with tapered ends. Their average size is $1-2 \mathrm{~cm}$, but they can reach even $5-6 \mathrm{~cm}$ and are surrounded by a typical darkgrey serpentinite matrix. Based on their shapes, these bastites could have formed by the alteration of pyroxene and/or amphibole (Fig. 3b), resulting in a set of homogeneous, fibrous serpentine crystals, which are lizardite based on Raman spectroscopy (Fig. 4c).

A majority of the analysed samples are intensively deformed (sheared serpentinites). Instead of nearly isometric cells in the typical mesh, oval-shaped cells appear (Fig. 3c). Their longer axes are $0.5-0.6 \mathrm{~mm}$ and the shorter, perpendicular axes are $0.2-0.3 \mathrm{~mm}$. Stretched cells define the $\mathrm{S}_{1}$ foliation. In the central parting of the mesh, magnetite strings have lengths approximately equal to those of the cells and are parallel to the $S_{1}$. At right angles, another system of magnetite veins can be identified. In cases, an elongated double-rim curtain-like texture (Francis 1956) occurs and denotes the $\mathrm{S}_{1}$ foliation. Large amounts of chlorite also occur along $\mathrm{S}_{1}$.

In a majority of the samples, the pervasive $\mathrm{S}_{1}$ foliation is crosscut by $\mathrm{S}_{2}$ foliation at a high angle $\left(\sim 80^{\circ}\right)$, resulting in the recrystallization of the pseudomorphous serpentinite. Thus, interlocking and interpenetrating textures developed (Fig. 3d), in which lizardite (Srp1) was transformed to antigorite (Srp2) (Fig. 3e, Fig 4d). In ultramafic-bearing samples, incompetent serpentinite aligns along $\mathrm{S}_{2}$ around the more competent relic cores. Numerous kinematic indicators appear along $S_{2}$, presenting unambiguous proof of shearing. The most common are rotation structures around bastites (Fig. 3f). During shearing, the bastites underwent recrystallization and the edges of the homogeneous Srp1 were transformed into fine-grained serpentines; tails developed parallel to the 

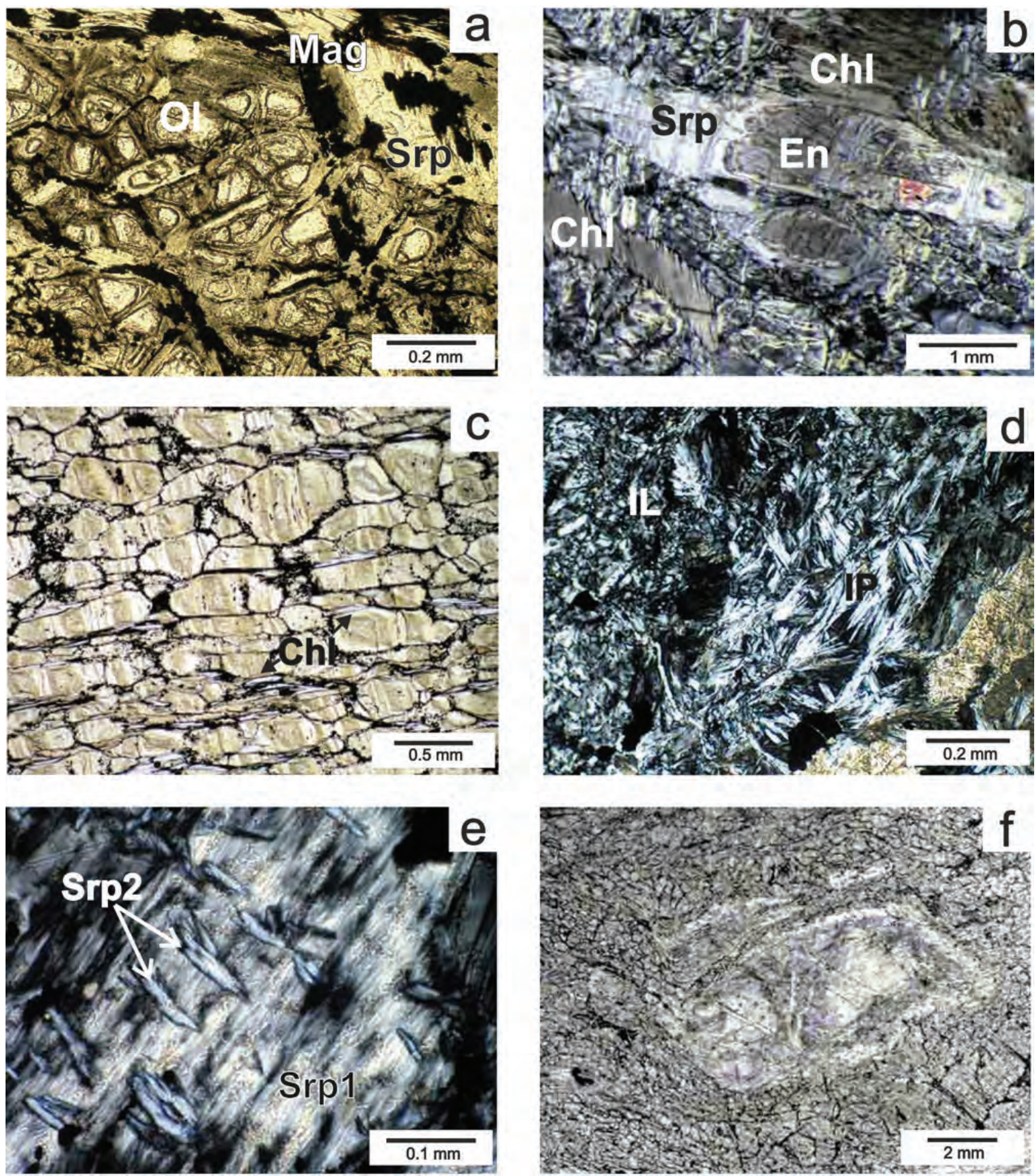

Fig. 3 Typical microtextures of the Gyód serpentinite. a - Incipient serpentinization of olivine (XPL). $\mathbf{b}$ - Enstatite remnant (En) in the serpentine pseudomorph (Opx bastite) (Srp) (XPL). c - Deformed cells in the mesh texture. Magnetite grains in the central partings of the mesh cells form a continuous, closed net. Chlorite (Chl) bundles define the foliation (PPL). d - Non-pseudomorphous serpentinite. IL = interlocking and IP $=$ interpenetrating texture of the serpentine needles (PPL). e - Recrystallized serpentine needles (Srp2) that define an interpenetrating texture in the pseudomorphous-textured serpentinite (Srp1) (XPL). f - Porphyroclast formed by a pre- and synkinematic serpentine pseudomorph. Microfractures developed in the tails, and recrystallization is identified at the edges of the clast (PPL).

shearing. These pressure shadows contain new generation of serpentine minerals (Srp2) identified as antigorite by the Raman spectroscopy (Fig. 5a). The Srp2 coexists with chlorite (Chl2) and talc (Fig. 6a). 

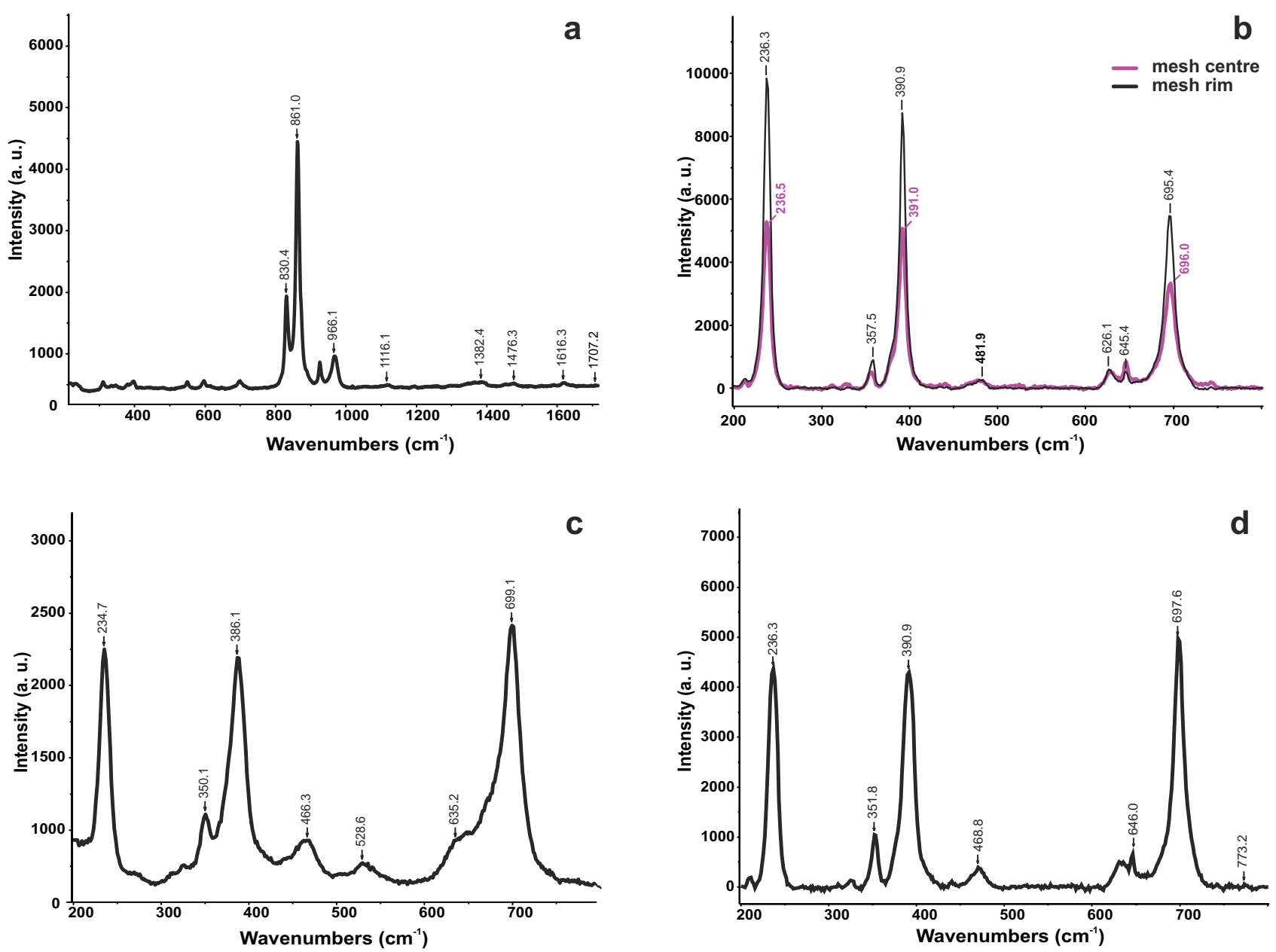

Fig. 4 Characteristic Raman spectra from the Gyód and Helesfa serpentinites I. a - Raman spectrum of forsteritic olivine (sample 7006). b Lizardite in the mesh centre and rim (sample 7027). c - Lizardite in the bastite after enstatite (sample 7084). d - Antigorite in the recrystallised lizardite bastite (sample 7084).

Significant amounts of carbonate minerals appear in both the protolith lenses and serpentine matrix. Carbonate also occurs in monomineralic and complex veins, which penetrate the serpentinite. According to the XRD data, the major carbonate phase in each textural position is dolomite, but magnesite also occurs (Kovács et al. 2003).

\subsubsection{Helesfa serpentinite}

Most core material from the Helesfa-1 drilling consists of massive, dark-grey, homogeneous serpentinite, which can be subdivided into three textural classes that are based on microscopic examinations and in part resemble the particular subclasses of the GS.

The most common serpentinite type in HS is typical serpentinite, which consists of small, dark-grey to green grains. It is formed by diverse types of mesh textures that formed after olivine. The centre of the mesh cells is composed of unstructured, microcrystalline serpentine, and is surrounded by fibrous serpentine rims (Fig. 7a); based on Raman spectroscopy, both parts of the mesh are lizardite (Fig. 5b). The cells reach $250-300 \mu \mathrm{m}$ in size and mostly have irregular shapes; isometric polygons are not characteristic. Secondary magnetite is rare, and opaque minerals are concentrated along the mesh rims and in the central fractures, which are usually not continuous. Numerous subtypes of pseudomorphous textures developed due to the deformation of the cells. As a result, the cells grew together and their centres became elongated, but their optical properties remained identical to those in the undeformed mesh centres.

The original minerals parental to the bastites in HS cannot be recognized. The bastites have millimetrescale lengths and show elongated, pillared shapes and olive-green colour. They contain chlorite crystals with a wide range of sizes $(10-300 \mu \mathrm{m})$, in addition to serpentinites (Fig. 7b). The open edges of the chlorites were assimilated by the serpentines, chrysotile according to the Raman spectroscopy (Fig. 5c). The bastites are sur- 

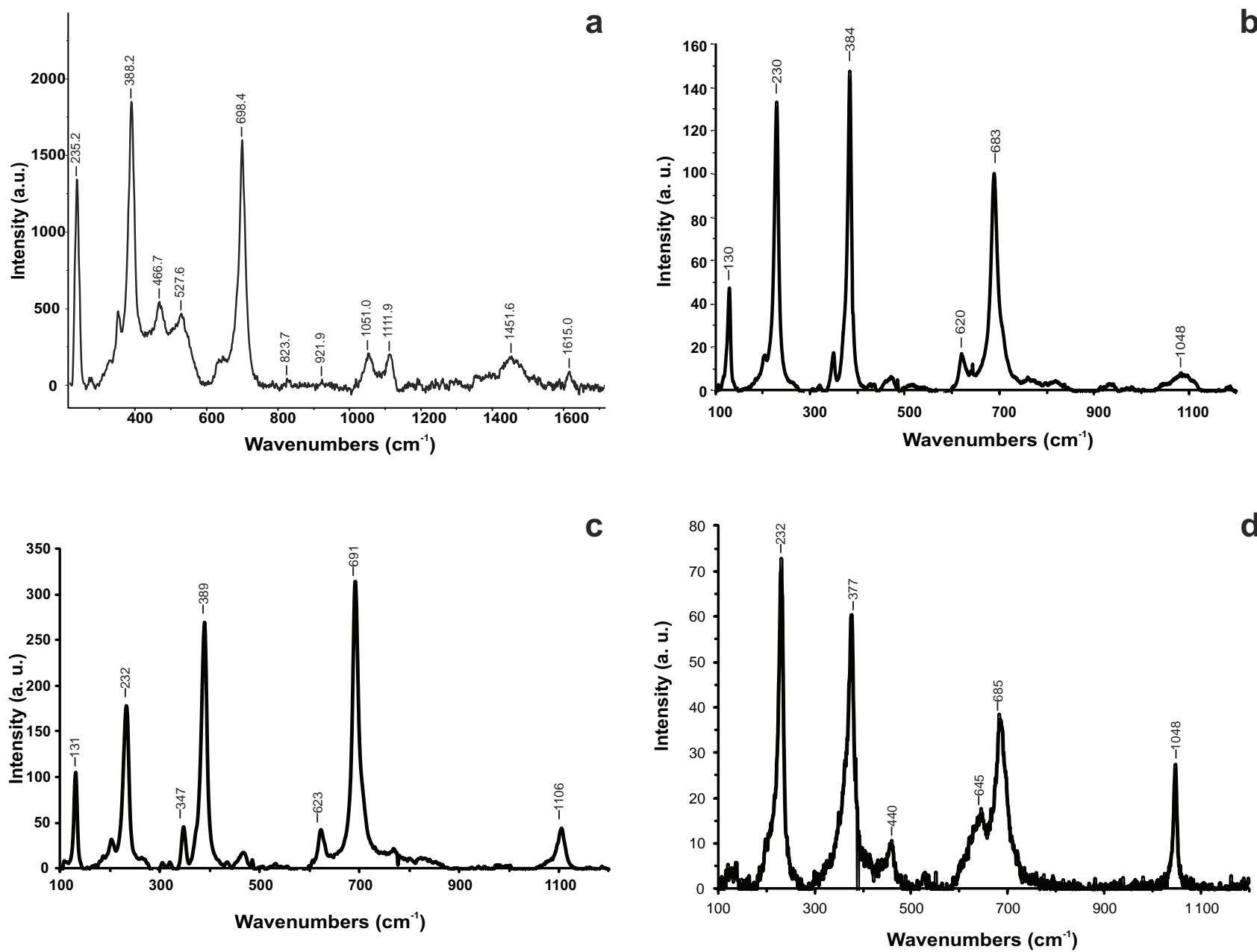

Fig. 5 Characteristic Raman spectra from Gyód and Helesfa serpentinites II. a - Lizardite and antigorite spectrum in the S, shear zone in the GS (sample 7083). b - Lizardite spectrum in the mesh rim from the HS (sample 7056). c - Chrysotile spectrum in the bastite from the HS (sample 7062). $\mathbf{d}$ - Antigorite spectrum in the tail of porphyroblast from the HS (sample 7056).

rounded mainly by non-pseudomorphous serpentinite. Microfractures usually occur perpendicular to the long axes of the bastites and are filled by non-pseudomorphous serpentine.

Banded or curtain-like textures (Francis 1956) appear in several rock samples. In this type of texture, mesh centres are unidentifiable; the rims are ribbon-like and reach centimetre-scale lengths in places. Curtain-like mesh rims define the $\mathrm{S}_{1}$ foliation (Fig. 7c). Based on the results of Raman spectroscopy, the transition texture of the serpentinite includes lizardite. Zones dominated by $\mathrm{Mg}$-amphibole that exhibits irregular, nest-shaped assemblages also appear. Along the edges, amphiboles are resorbed by talc and non-pseudomorphous antigorite (Fig. 7d).

The second most common serpentinite type of the HS is the foliated serpentinite. It shows clear evidence of two foliations, whereby the $S_{2}$ crosscuts the $S_{1}$ fabric (Fig. 7e) and is defined by kinematic indicators ( $\sigma$-clasts, boudinage, and S-shaped bastites). At the wings of the $\sigma$-clasts, interpenetrating textures often appear inside and around the bastites, consisting of needle-shaped antigorite crystals (Fig. 6b). In the sheared parts of the rocks, both mesh and transition textures are overprinted by interlocking or interpenetrating antigorite (Fig. 5d). In addition to antigorite, chlorite (Chl2) and talc appear along the $\mathrm{S}_{2}$ foliation. Secondary magnetite-bearing zones developed along the $\mathrm{S}_{2}$ foliation in those parts where $\mathrm{D}_{2}$ deformation was significant.

Late carbonatization is characteristic in the HS samples; in cases, magnesite occurs in the mesh centre (Fig. 7f). However, the high-grade alteration of both mesh- and transition-textured serpentinite is typical, whereby the fine-grained carbonate matrix totally replaces the serpentine minerals.

Fig. 6 The Raman map of Srp2. a - Antigorite crystals occur as Srp2 in the GS. $\mathbf{b}$ - The Raman map of Srp2 in the HS. Antigorite crystals occur in the tails of the $\sigma$-clast. 

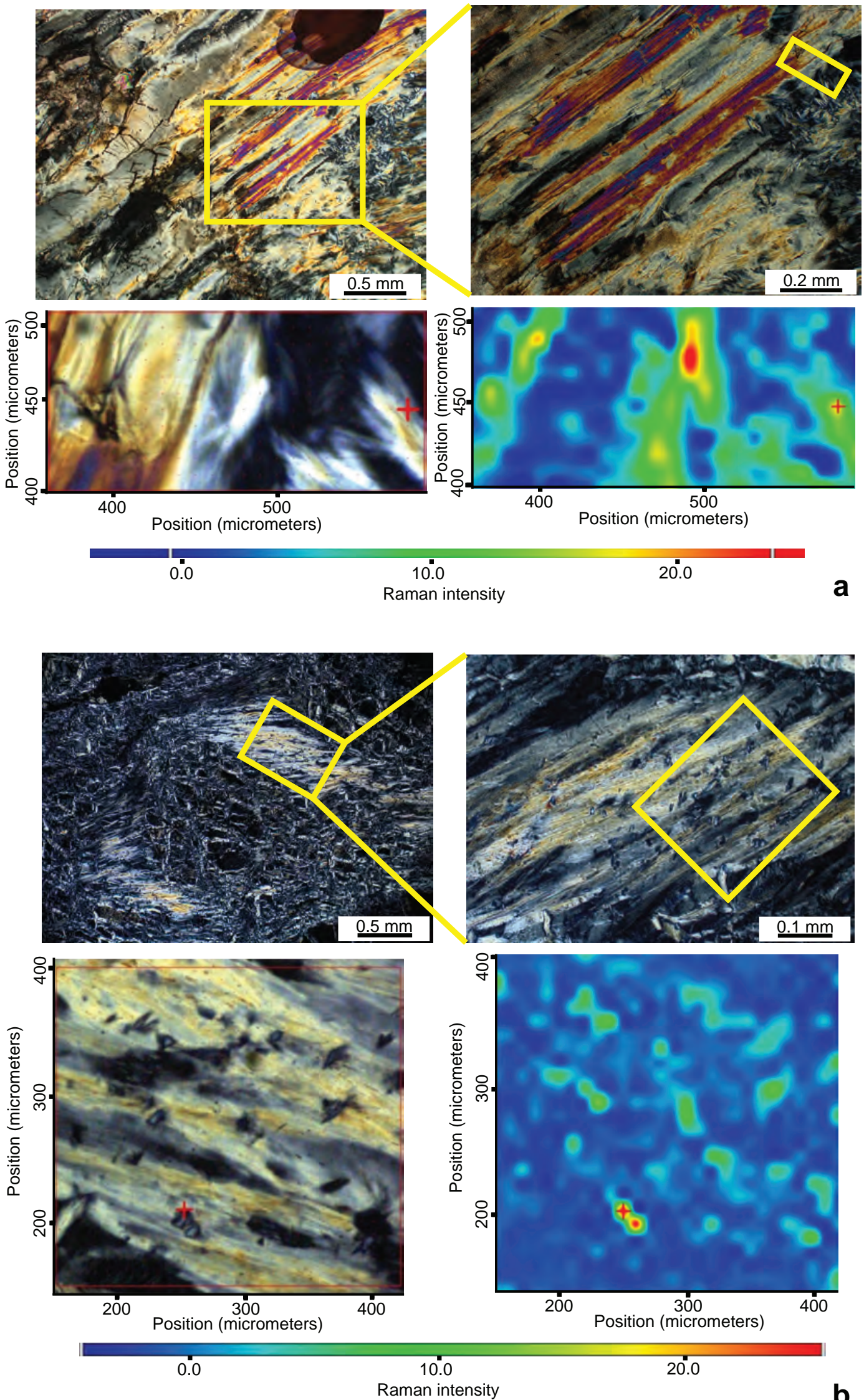

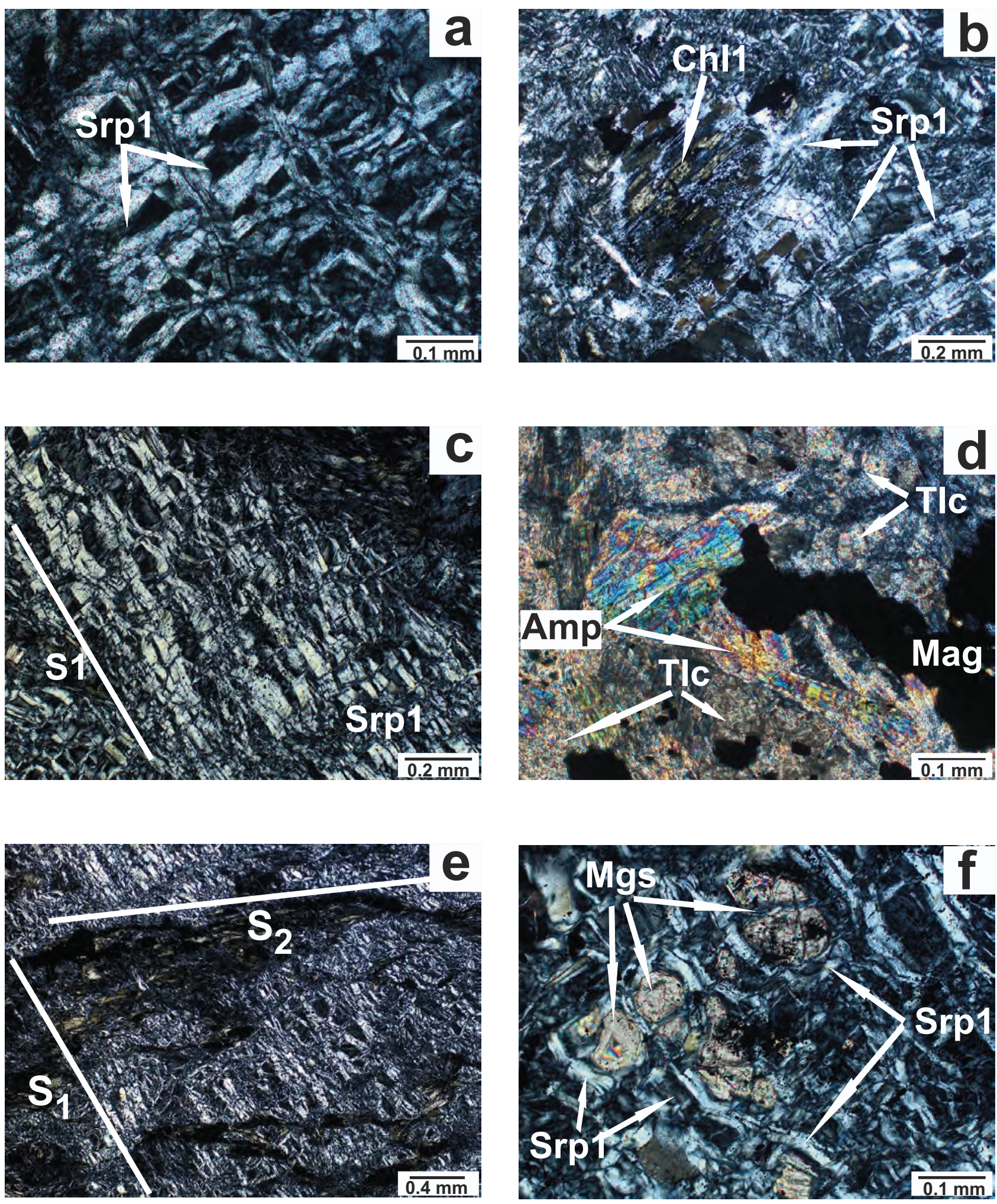

Fig. 7 Typical microtextures of the Helesfa serpentinite. a - Mesh cells in the pervasively serpentinized ultramafic domain (XPL). b - Oriented chlorite (Chl1) and serpentine (Srp1) crystals that define the foliation in the transition texture serpentinite (XPL). c - Curtain-like texture, with rims formed by fibrous serpentine (XPL). d - Mg-amphibole (Amp) and talc (Tlc) assemblage in the HS (XPL). e - Foliation in the curtain-like serpentinite $\left(\mathrm{S}_{1}\right)$ overprinted by the mylonitized zone of $\mathrm{S}_{2}(\mathrm{XPL}) . \mathbf{f}$ - Magnesite occurring in the mesh centres, and mesh rims that are formed by fibrous serpentine (Srp1) (XPL). 


\subsection{Major-element chemistry}

The serpentinization degree of the originally dry ultramafic rocks can be approximated by the amount of LOI. Following Parkinson and Pearce (1998), the whole-rock data were recalculated to dry basis because the LOI would be different for different areas, samples or even domains within samples. The melting/differentiation trends of the GS samples are shown on Fenner diagrams (Fig. 8). The isocon method of Gresens (1967) and its graphic form by Grant (1986) are used (Fig. $9 \mathrm{a}-\mathrm{d})$ to assess the role of element mobilization. The bulk data for our own serpentinite samples are compared with the least serpentinized sample from the GS as well as the published data for average harzburgite (Coleman 1977).

\subsubsection{Gyód serpentinite}

The LOI values of the GS samples vary between 11.2 and 15.0 wt. \%, suggesting different degrees of serpentinization (Tab. 4). The $\mathrm{SiO}_{2}$ contents are 43.05-45.05 wt. \% (Fig. 8a), $\mathrm{MgO}$ is $43.98-45.37$ wt. \%, and the $\mathrm{SiO}_{2} / \mathrm{MgO}$ ratios (by weight) are nearly constant, between 0.95 and 1.02. The $\mathrm{Al}_{2} \mathrm{O}_{3}$ values fall between 1.05 and 2.69 wt. \% (Fig. 8b); two groups of samples, with higher and lower $\mathrm{Al}_{2} \mathrm{O}_{3}$ contents, can be defined. The contents of $\mathrm{CaO}$ are less than 1 wt. $\%$ (Fig. 8c), $\mathrm{Fe}_{2} \mathrm{O}_{3}$ TOT $=7.66-10.40$ wt. $\%$ (Fig. $8 \mathrm{~d}$ ) and $\mathrm{TiO}_{2}<0.13$ wt. \% (Fig. $8 \mathrm{e})$. The $\mathrm{Mg} \#$ values $(\mathrm{Mg} \#=$ $100 \times \mathrm{Mg} /(\mathrm{Mg}+\mathrm{Fe}))$ of the serpentinite samples are high and define a very narrow interval (90.1-92.7).

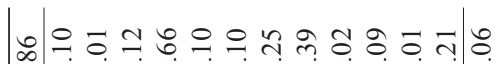

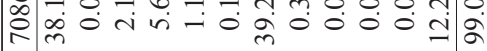

सก

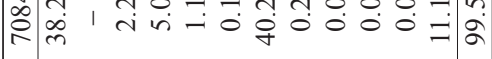
กำ

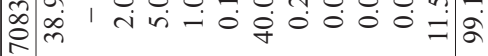
金守

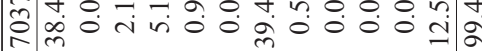

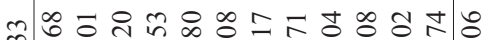
री

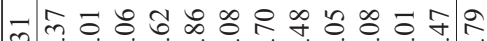
尺ी n๒

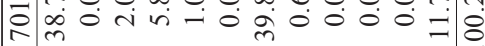

m

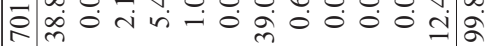

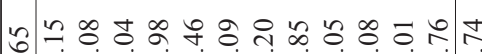

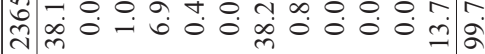

toำ

لَّ

대융

तो

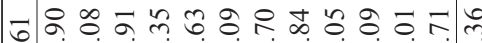
đill

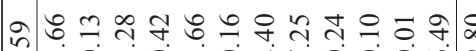

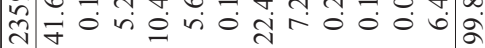

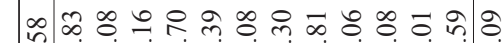
品

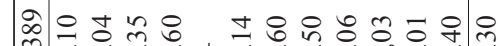

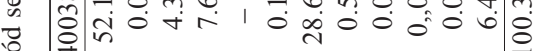

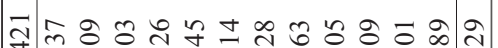

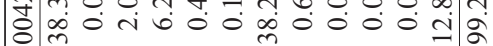

tงำำ

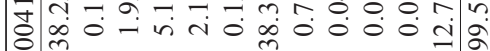

म্

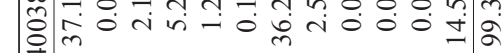

ㅇํำ ำ ํำ

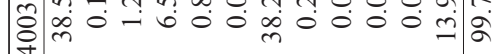

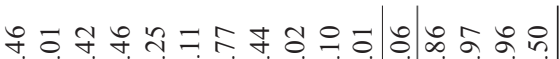
mo

응 字 1 तn

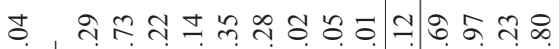

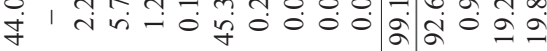

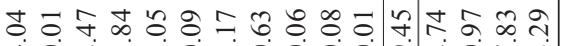

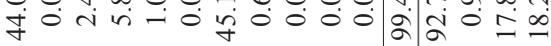

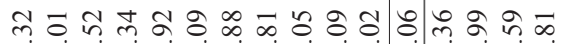

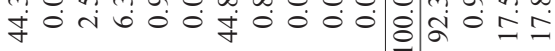
బ ప भं०

क

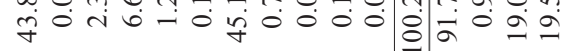
4
$z$

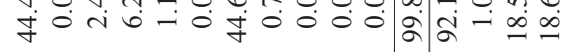
ㄴํㅇ

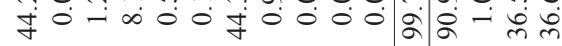

$\overrightarrow{4} \approx 0$ 药 भें

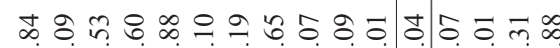

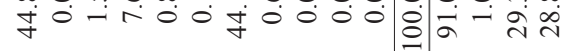

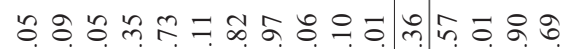

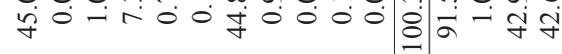

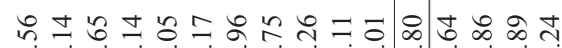

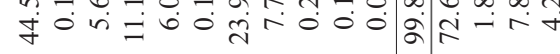

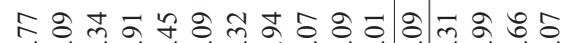

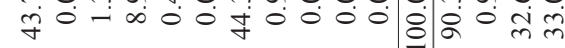

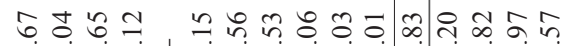

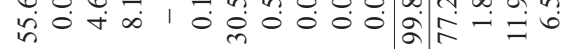

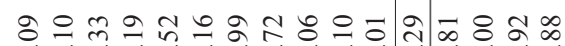

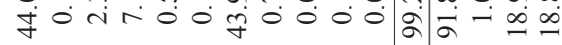
$\curvearrowleft=$ กิ $\dot{d} 0$
$\infty$
$\infty$

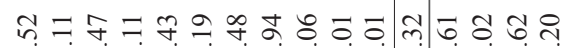
dिं

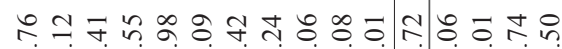

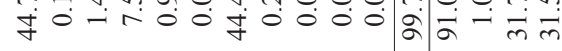

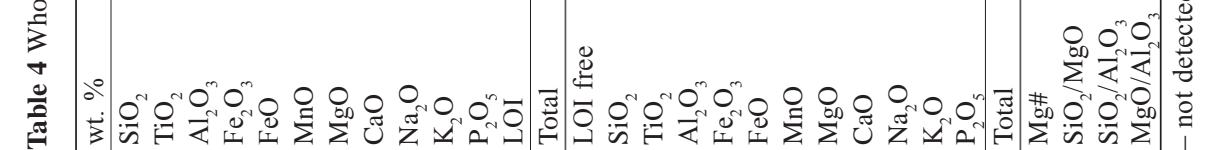

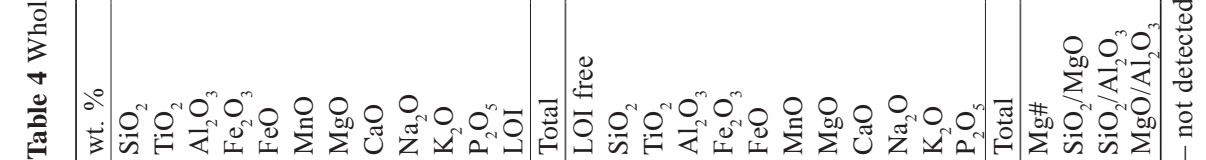



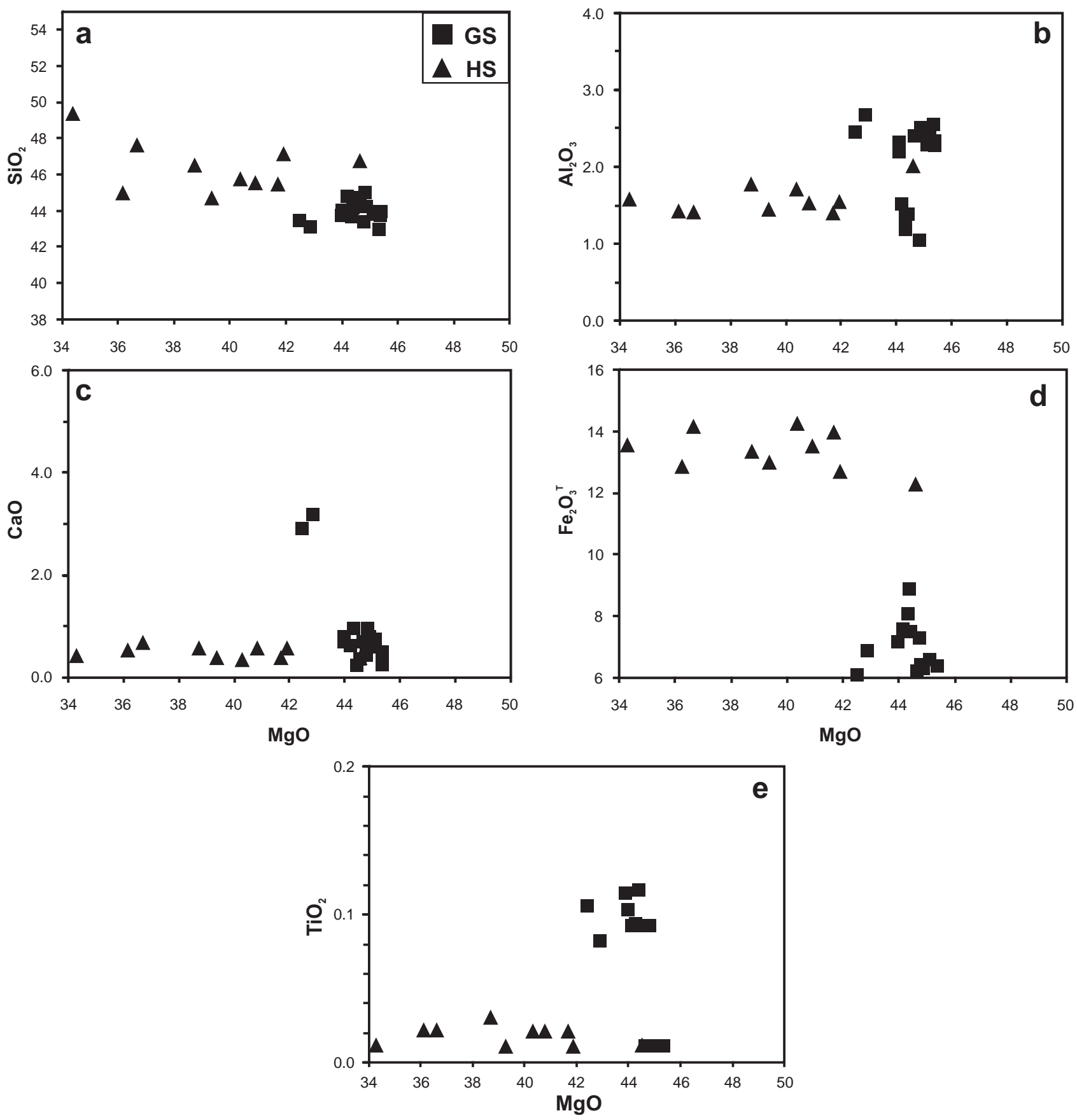

Fig. 8a-e Fenner-type diagrams showing the chemical variations in the major elements of the Gyód and Helesfa serpentinites.

Based on the element mobilization analysis, the metamorphism was close to isochemical because the LOI values and $\mathrm{SiO}_{2} / \mathrm{MgO}$ ratios are not correlated (Bashir et al. 2012). Due to this assumption the slope of the isocon is 1. Based on Grant (1986) the protolith geochemical data are shown on the $\mathrm{X}$ axis and the altered rock data on the $\mathrm{Y}$ axis. Oxides located above the isocon increased during metamorphism, those under the isocon were depleted. As the main oxides align rather close to the isocon, their amount did not change significantly during the alteration.
For numerous differently altered serpentinite samples, like in case of GS1 a slight decrease in $\mathrm{Fe}_{2} \mathrm{O}_{3}{ }^{\text {TOT }}, \mathrm{MnO}$, $\mathrm{CaO}$ and $\mathrm{Na}_{2} \mathrm{O}$ is typical, while $\mathrm{Al}_{2} \mathrm{O}_{3}$ increases compared to the average harzburgite (Fig. 9a). This last trend is proven by the comparison with the least serpentinized GS sample (GS2), as well. For $\mathrm{TiO}_{2}$, the more serpentinized samples show a more depleted nature than those containing relict domains (Fig. 9b). Most of the samples plot in the harzburgite field (Streckeisen 1976) based on the CIPW norm (Fig. 10). 

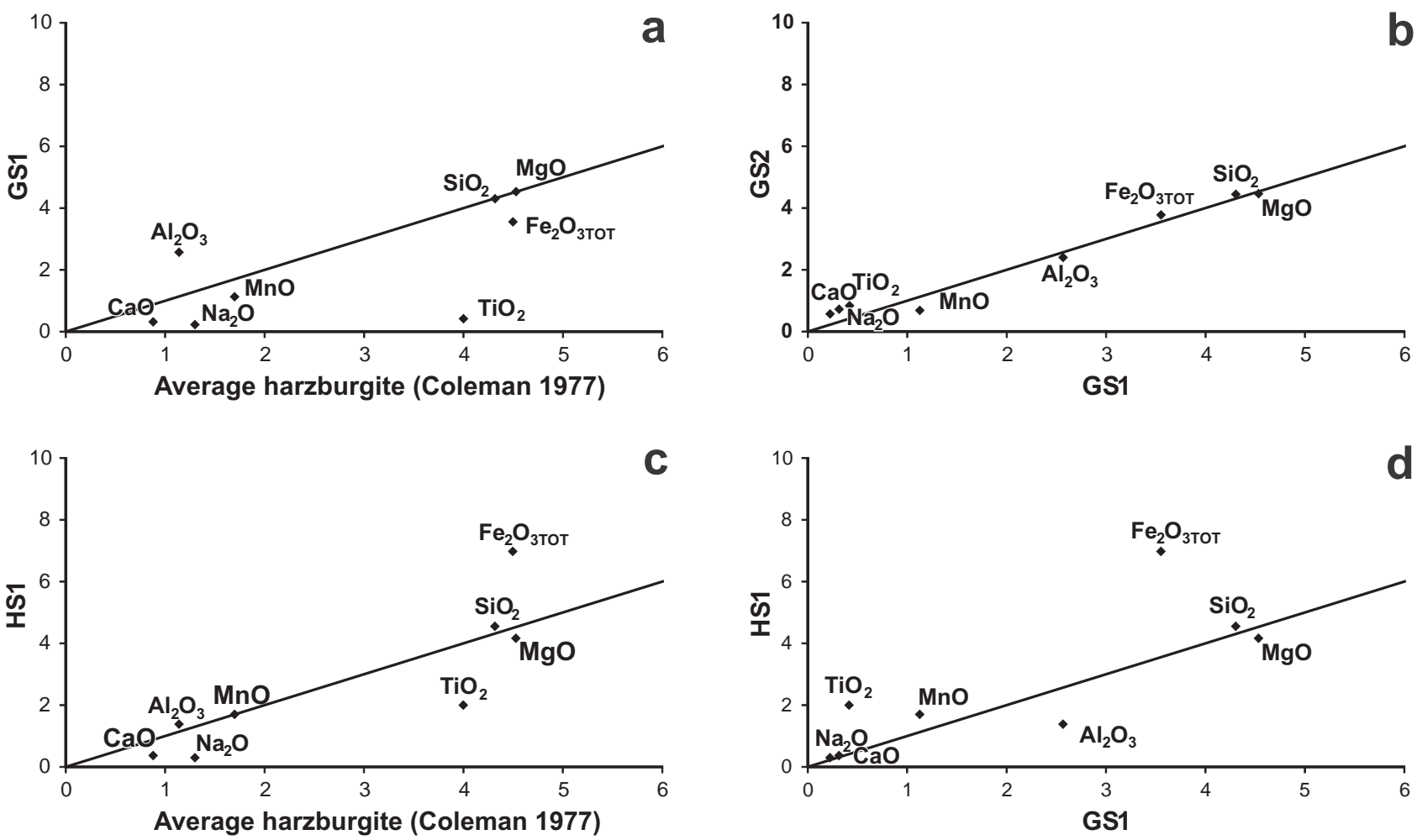

Fig. 9 Isocon diagrams testing the potential element mobilization in the $\mathrm{GS}$ and $\mathrm{HS}$ bodies $\left(\mathrm{SiO}_{2} / 10, \mathrm{TiO}_{2} \times 100, \mathrm{Fe}_{2} \mathrm{O}_{3}^{\mathrm{TOT}} / 2, \mathrm{MnO} \times 10, \mathrm{MgO} / 10\right.$, $\mathrm{Na}_{2} \mathrm{O} \times 100, \mathrm{~K}_{2} \mathrm{O} \times 10$ ). $\mathbf{a}$ - Comparison of the ultramafic sample GS1 to an average harzburgite (Coleman 1977). $\mathbf{b}$ - Comparison of a serpentinized sample GS2 to the ultramafic sample GS1. c - Comparison of a serpentinized sample HS1 to an average harzburgite (Coleman 1977). d-Comparison of a serpentinized sample HS1 to the ultramafic sample from the GS (GS1).

The igneous differentiation tendencies of the GS samples are shown on Fenner diagrams and are compared to typical ultramafic rocks from the literature (abyssal ultramafic rocks: Parkinson and Pearce 1998; Pearce et al. 2000; Alpine-type ultramafic rocks: Melcher et al. 2002; ophiolite series: Jaques and Chappell 1980; Monnier 1999). The trend shows a moderately depleted protolith. In the $\mathrm{Al}_{2} \mathrm{O}_{3}-\mathrm{FeO}^{\text {TOT }}-\mathrm{MgO}$ (AFM) diagram (Fig. 11), the GS samples plot among the depleted rocks, close to the continental xenoliths and depleted oceanic peridotites.

\subsubsection{Helesfa serpentinite}

The LOI values of the analysed HS samples vary between 12.5 and 14.1 wt. \% (Tab. 5); the geochemical compositions of the petrographically different serpentinite types are not significantly different. The $\mathrm{SiO}_{2}$ content ranges between 44.49 and 49.35 wt. $\%, \mathrm{MgO}$ is $34.32-42.18$ wt. $\%$, and $\mathrm{SiO}_{2} / \mathrm{MgO}$ ratios are $1.05-1.44$. The amount of $\mathrm{TiO}_{2}$ is $0.01-0.03$ wt. \%, that of $\mathrm{CaO}$ is $0.34-0.68$ wt. \%, that of $\mathrm{Al}_{2} \mathrm{O}_{3}$ is $1.33-1.88$ wt. \%, and that of $\mathrm{Fe}_{2} \mathrm{O}_{3}{ }^{\text {TOT }}$ is 12.29-14.24 wt. \% (Fig. 8a-e). The Mg\# values of the serpentinite samples fall within a tight interval (83.487.8), suggesting a less depleted nature than is typical of the GS samples.
Geochemical compositions of a serpentinized HS sample (HS1) and an average harzburgite were compared by the isocon method. The $\mathrm{SiO}_{2}$ and $\mathrm{MgO}$ contents do not show significant modification; the depletion in $\mathrm{CaO}$ and $\mathrm{TiO}_{2}$ is moderate, while the increase in $\mathrm{Fe}_{2} \mathrm{O}_{3}{ }^{\text {TOT }}$ is considerable. The $\mathrm{Al}_{2} \mathrm{O}_{3}$ contents show a slight increase (Fig. 9c). Compared to the reference GS sample, the

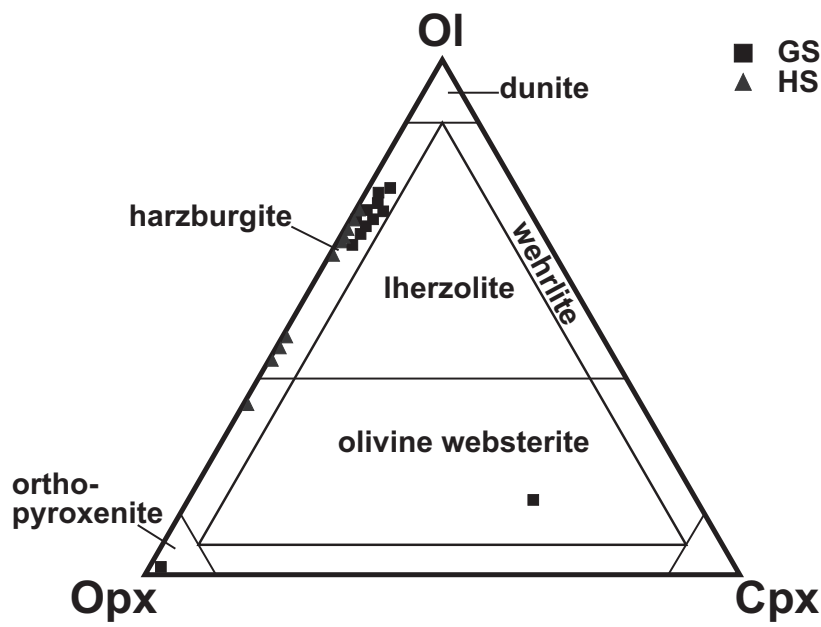

Fig. 10 CIPW normative composition of GS and HS plotted in the classification diagram of ultramafic rocks, after Streckeisen (1976). 
Table 5 Whole-rock major-element analyses from Helesfa serpentinite

\begin{tabular}{|c|c|c|c|c|c|c|c|c|c|c|}
\hline wt. \% & 7053 & 7057 & 7061 & 9-K-0527 & 9-K-0734 & 9-K-0739 & 9-K-0742 & 9-K-0501 & 9-K-0519 & 9-K-0749 \\
\hline $\mathrm{SiO}_{2}$ & 38.52 & 38.78 & 38.84 & 42.8 & 38.07 & 39.54 & 38.63 & 40.11 & 39.95 & 40.96 \\
\hline $\mathrm{TiO}_{2}$ & 0.02 & 0.01 & 0.02 & 0.01 & 0.01 & 0.01 & 0.01 & 0.02 & 0.02 & 0.02 \\
\hline $\mathrm{Al}_{2} \mathrm{O}_{3}$ & 1.27 & 1.25 & 1.45 & 1.35 & 1.15 & 1.29 & 1.64 & 1.51 & 1.25 & 1.21 \\
\hline $\mathrm{Fe}_{2} \mathrm{O}_{3}$ & 11.42 & 11.26 & 12.09 & 11.75 & 11.68 & 10.65 & 10.14 & 11.51 & 11.43 & 12.18 \\
\hline $\mathrm{FeO}$ & - & - & - & - & - & - & - & - & - & - \\
\hline $\mathrm{MnO}$ & 0.15 & 0.12 & 0.16 & 0.1 & 0.14 & 0.12 & 0.16 & 0.14 & 0.13 & 0.18 \\
\hline $\mathrm{MgO}$ & 34.57 & 34.15 & 34.26 & 29.76 & 34.87 & 35.13 & 36.82 & 33.38 & 32.14 & 31.52 \\
\hline $\mathrm{CaO}$ & 0.47 & 0.34 & 0.3 & 0.36 & 0.31 & 0.5 & 0.32 & 0.49 & 0.46 & 0.58 \\
\hline $\mathrm{Na}_{2} \mathrm{O}$ & 0.03 & 0.03 & 0.05 & 0.04 & 0.03 & 0.05 & 0.04 & 0.03 & 0.04 & 0.05 \\
\hline LOI & 13.38 & 13.11 & 13.06 & 13.19 & 13.19 & 12.49 & 12.77 & 13.97 & 14.19 & 14.12 \\
\hline Total & 99.82 & 99.05 & 100.21 & 99.36 & 99.45 & 99.78 & 100.53 & 101.15 & 99.61 & 100.82 \\
\hline \multicolumn{11}{|l|}{ LOI free } \\
\hline $\mathrm{SiO}_{2}$ & 44.49 & 44.69 & 44.66 & 49.35 & 43.89 & 45.19 & 44.25 & 46.53 & 46.6 & 47.63 \\
\hline $\mathrm{TiO}_{2}$ & 0.02 & 0.01 & 0.02 & 0.01 & 0.02 & 0.01 & 0.01 & 0.03 & 0.02 & 0.02 \\
\hline $\mathrm{Al}_{2} \mathrm{O}_{3}$ & 1.46 & 1.44 & 1.66 & 1.56 & 1.33 & 1.47 & 1.88 & 1.76 & 1.45 & 1.41 \\
\hline $\mathrm{Fe}_{2} \mathrm{O}_{3}$ & 13.18 & 12.97 & 13.9 & 13.55 & 13.46 & 12.17 & 11.62 & 13.35 & 13.33 & 14.17 \\
\hline $\mathrm{FeO}$ & - & - & - & - & - & - & - & - & - & - \\
\hline $\mathrm{MnO}$ & 0.17 & 0.14 & 0.18 & 0.11 & 0.16 & 0.14 & 0.18 & 0.16 & 0.15 & 0.21 \\
\hline $\mathrm{MgO}$ & 39.92 & 39.36 & 39.39 & 34.32 & 40.2 & 40.16 & 42.18 & 38.72 & 37.48 & 36.66 \\
\hline $\mathrm{CaO}$ & 0.54 & 0.39 & 0.34 & 0.41 & 0.35 & 0.58 & 0.37 & 0.57 & 0.54 & 0.68 \\
\hline $\mathrm{Na}_{2} \mathrm{O}$ & 0.03 & 0.04 & 0.06 & 0.05 & 0.03 & 0.06 & 0.05 & 0.03 & 0.04 & 0.06 \\
\hline Total & 99.82 & 99.05 & 100.21 & 99.36 & 99.45 & 99.78 & 100.53 & 101.15 & 99.61 & 100.82 \\
\hline $\mathrm{Mg} \#$ & 85.71 & 85.73 & 84.87 & 83.38 & 85.54 & 86.73 & 87.79 & 85.17 & 84.77 & 83.67 \\
\hline $\mathrm{SiO}_{2} / \mathrm{MgO}$ & 1.11 & 1.14 & 1.13 & 1.44 & 1.09 & 1.13 & 1.05 & 1.20 & 1.24 & 1.30 \\
\hline $\mathrm{SiO}_{2} / \mathrm{Al}_{2} \mathrm{O}_{3}$ & 30.47 & 31.03 & 26.90 & 31.63 & 33.00 & 30.74 & 23.54 & 26.44 & 32.14 & 33.78 \\
\hline $\mathrm{MgO} / \mathrm{Al}_{2} \mathrm{O}_{3}$ & 27.34 & 27.33 & 23.73 & 22.00 & 30.23 & 27.32 & 22.44 & 22.00 & 25.85 & 26.00 \\
\hline
\end{tabular}

- not detected

depletion in $\mathrm{Al}_{2} \mathrm{O}_{3}$, and gain in $\mathrm{Fe}_{2} \mathrm{O}_{3}{ }^{\mathrm{TOT}}$, $\mathrm{MnO}$ and $\mathrm{TiO}_{2}$ are characteristic of HS samples (Fig. 9d).

Most samples plot in the harzburgite field (Streckeisen 1976) (Fig. 10) based on the CIPW norm. This type of protolith is partly supported by the comparison

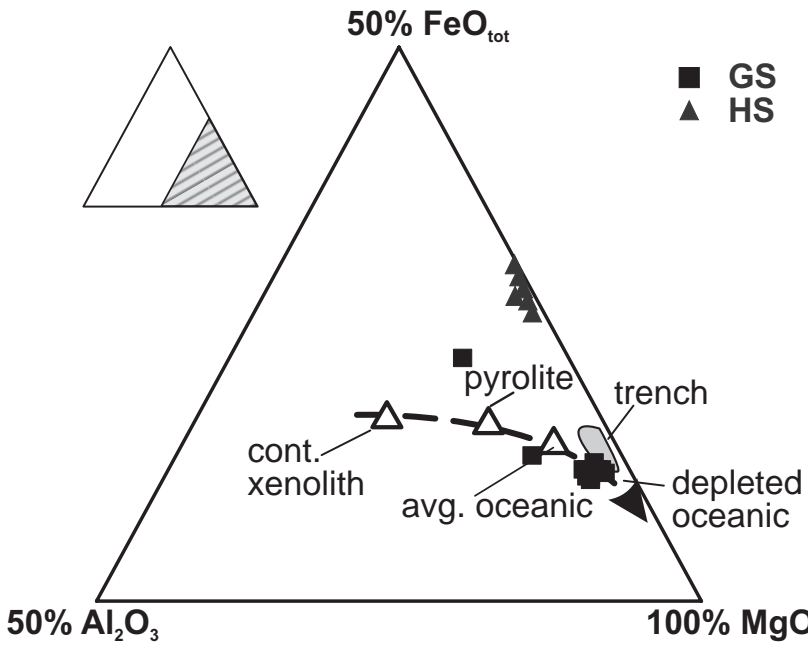

Fig. 11 Relationship between GS and HS and their tectonic settings in the AFM diagram $\left(\mathrm{Al}_{2} \mathrm{O}_{3}-\mathrm{FeO}^{\mathrm{TOT}}-\mathrm{MgO}\right.$, all wt. \%); the data for ultramafic rocks from various tectonic regimes are from Bonatti and Michael (1989). of our geochemical data with fields of ultramafic rocks from the literature as for GS (Fig. 12). On the $\mathrm{Al}_{2} \mathrm{O}_{3}-$ $\mathrm{FeO}^{\text {TOT }}-\mathrm{MgO}$ diagram, the $\mathrm{HS}$ samples are separated from typical peridotites because of the high iron contents (Fig. 11).

\subsection{Thermometry}

The retrograde metamorphic pathway of the original harzburgite can be reconstructed by calculating the stability fields of the subsequently hydrated mineral phases. According to our model, amphibole formed during the low-grade hydration of the Opx-rich protolith, resulting in $\mathrm{Ol}+\mathrm{En}+\mathrm{Tr}+$ Ath paragenesis (Fig. 13). The formation of anthophyllite is a pressure-sensitive reaction, so pressure of $0.2-0.4 \mathrm{GPa}$ can be estimated. The petrographic investigations correspond well to the stability field of the lizardite + chrysotile + chlorite assemblage in the $T-\mathrm{XH}_{2} \mathrm{O}$ system (Fig. 14), suggesting that the main serpentinization took place at $230-250{ }^{\circ} \mathrm{C}$.

The antigorite is stable at higher temperature than lizardite and chrysotile. Moreover, antigorite and talc coexist at lower hydration levels. As a consequence, the formation of minerals along the $\mathrm{S}_{2}$ foliation required rising temperature and dehydration coevally. As there is no 


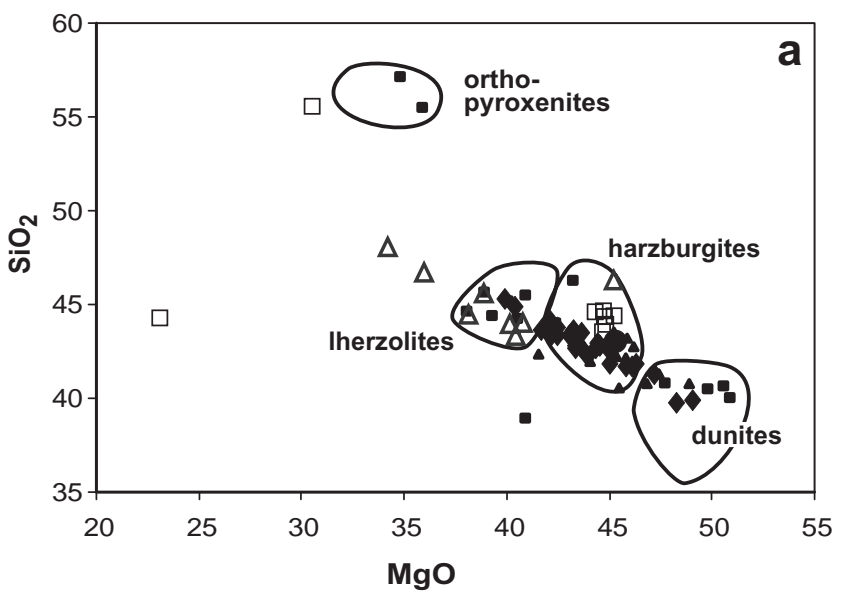

$\begin{array}{lll}\square & \text { GS } & \\ \Delta & \text { HS } & \begin{array}{l}\text { average harzburgite } \\ \text { (Coleman 1977) }\end{array} \\ \text { Alpine-type ultramafites } \\ \text { (Melcher et al. 2002) }\end{array}$

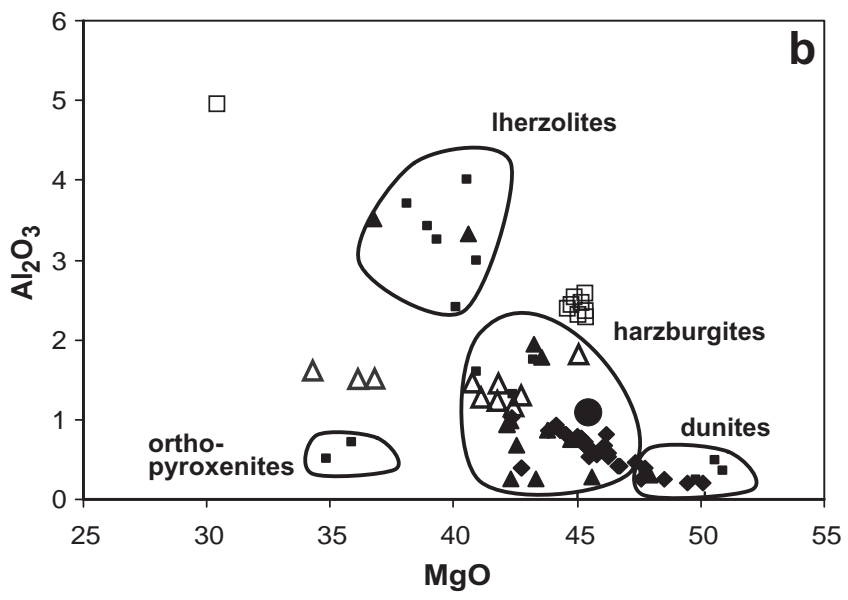

abyssal ultramafites

(Parkinson and Pearce 1998)

abyssal ultramafites

(Pearce et al. 2000)

Fig. 12 Discrimination diagrams (Coleman 1977; Parkinson and Pearce 1998; Pearce et al. 2000; Melcher et al. 2002). a - Comparison of GS and HS compositions and published ultramafic rocks in the $\mathrm{MgO}-\mathrm{SiO}_{2}$ diagram (wt. \%). b - Comparison of GS and HS compositions and published ultramafic rocks in the $\mathrm{MgO}-\mathrm{Al}_{2} \mathrm{O}_{3}$ diagram (wt. \%).

pressure-sensitive reaction in this system, the pressure conditions could not be accurately determined.

\section{Discussion}

\subsection{Petrology of the two serpentinite bodies}

The geological positions of the two serpentinite bodies are similar. Both are elongated over several kilometres and rootless and have a tectonic contact with their surroundings, which are markedly different petrographically. The Helesfa serpentinite is enclosed by granite and the Gyód serpentinite by paragneiss and amphibolite. Both bodies can be found in the uppermost part of the crystalline basement; Pliocene and Pleistocene sediments cover them unconformably. There are many similarities concerning the petrology of GS and HS, and their common development included these main events.

\subsubsection{Upper mantle stage - the composition of the protolith}

The Gyód serpentinite preserves a significant amount of relict ultramafic rocks. Among the rock-forming protolith phases, olivine, orthopyroxene and spinel can be identified (Tabs 1-3).

As olivine- and Opx-rich domains appear separately in the serpentinite samples, the protolith may have been a heterogeneous, layered harzburgite. Although relict minerals are not present in the HS, based on its textural features, the original olivine (mesh) and orthopyrox- ene- and amphibole (bastite)-rich domains can still be reconstructed. Although the most typical mesh texture of the studied serpentinites is evidence for the previous presence of olivine, the precursor minerals of the bastites could be Opx, Cpx or even Amp (e.g., Haidinger 1845; Wicks and Whittaker 1977; Dungan 1979a, b). The formation of these pseudomorphs is most likely in rocks where the Ol/En ratio exceeds 0.7 (O'Hanley 1991, 1996)

The isocon analysis suggests that the metamorphism of the original ultramafic rocks was close to isochemical, so the composition of the serpentinite samples can be used to characterize the protolith geochemically. Compared to the literature data, the GS samples plot in the harzburgite field on the discrimination diagrams (Fig. 12), while two samples are orthopyroxenites and another one is olivine websterite. Most HS samples are harzburgites as well, although they plot close to the orthopyroxenite field.

Particular oxide ratios $\left(\mathrm{SiO}_{2} / \mathrm{MgO}, \mathrm{SiO}_{2} / \mathrm{Al}_{2} \mathrm{O}_{3}\right.$, and $\mathrm{MgO} / \mathrm{Al}_{2} \mathrm{O}_{3}$ ) in all the GS and $\mathrm{HS}$ samples are rather similar to each other, suggesting a possible relationship between the source rocks of the two bodies. Only the $\mathrm{Fe}_{2} \mathrm{O}_{3}{ }^{\mathrm{T}}$ content of the HS is significantly higher, which is in accord with the complete hydration and coeval oxidation of these samples (Sobolev 1952; Coleman 1977). This tendency was also confirmed between the least and most hydrated GS samples. The low $-\mathrm{Al}_{2} \mathrm{O}_{3}$ group of the GS samples overlaps with the HS samples.

In the Fenner diagrams, the data of the two localities appear separated; the HS samples fit well to the general depletion trend of the mantle ultramafics, whereas the GS fall at the most depleted end of the same trend. In addi- 


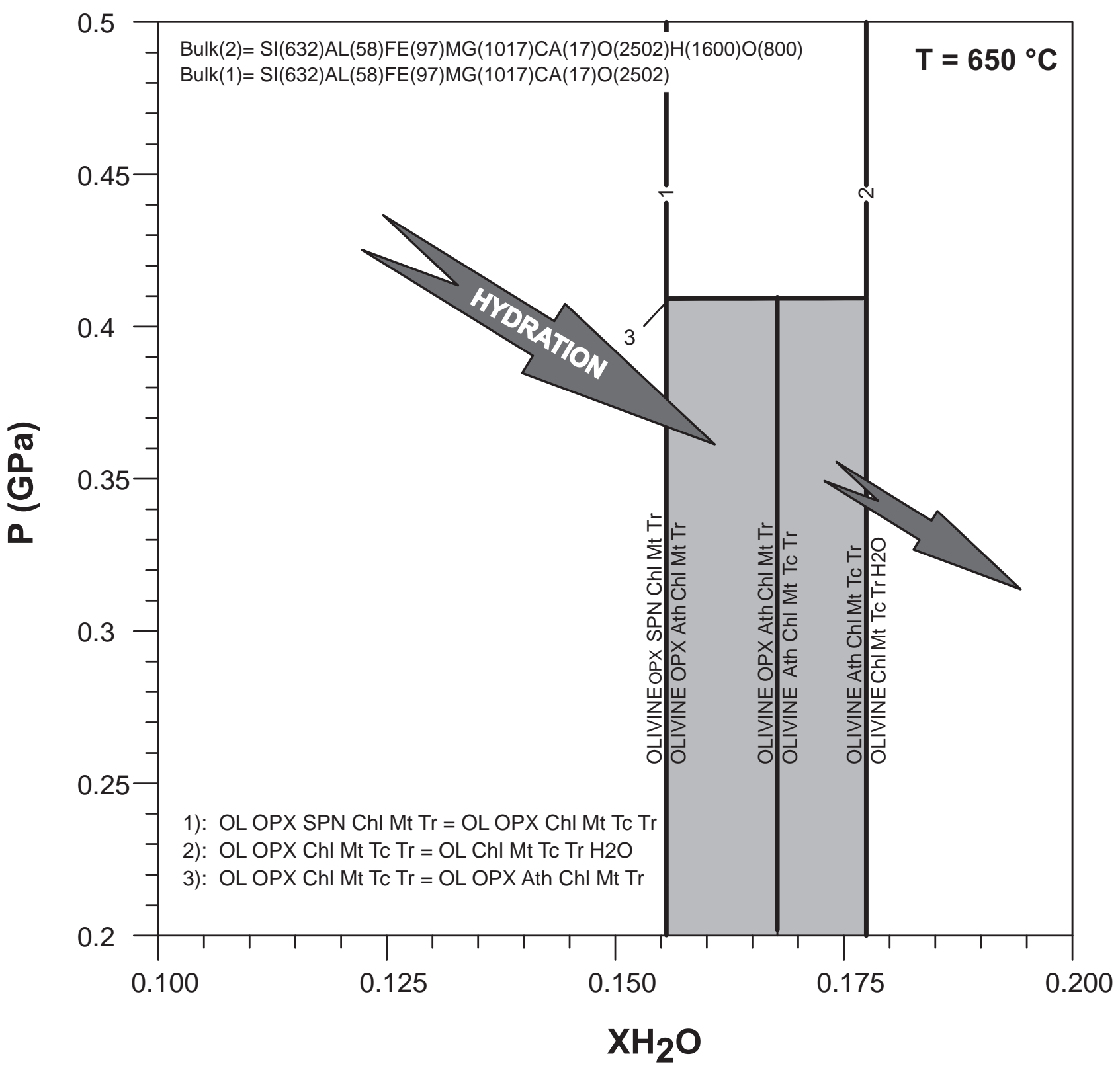

Fig. 13 Equilibrium paragenesis of ultramafic-bearing serpentinites in the $P-T$ diagram. For details, see the text.

tion, both Mg\# and Ni contents of the GS olivine are rather close to those typical of the mantle-derived olivine (Brown 1980; Takahashi et al, 1987) in ophiolitic peridotites (e.g. Niida 1997; Pearce et al. 2000). The high proportion of Fo component $\left(\mathrm{Fo}_{90.4-91)}\right.$ in the GS (Tab. 1) refers to the depleted characteristic of the upper mantle derived peridotites. According to Dick and Bullen (1984), the Cr\# is suitable to estimate the depletion process of the mantle: low $\mathrm{Cr} \#$ $(<0.6)$ indicates relatively small degree of partial melting of mantle, while the high $\mathrm{Cr} \#(>0.6)$ is an indicator of the high degree of depletion. This is supported by petrographic observations, as the high Cr\# spinels generally occur in pyroxene-poor rock types (harzburgite, dunite).

\subsubsection{Mantle deformation stage}

The deformation of the relict protolith $\left(\mathrm{D}_{0}\right)$ can be detected by numerous features in the olivine- and pyroxene-rich domains. The pyroxene-bearing domains are more resistant to hydration, so more early deformation elements could be preserved here than in the olivine-rich ones. Enstatite neoblasts appear in the vicinity of the enstatite porphyroblasts, suggesting growth due to high-T recrystallization under upper mantle conditions. The composition of the olivine porphyroblasts and interstitial olivine grains is identical, likely representing a single generation regardless of their different textures. 


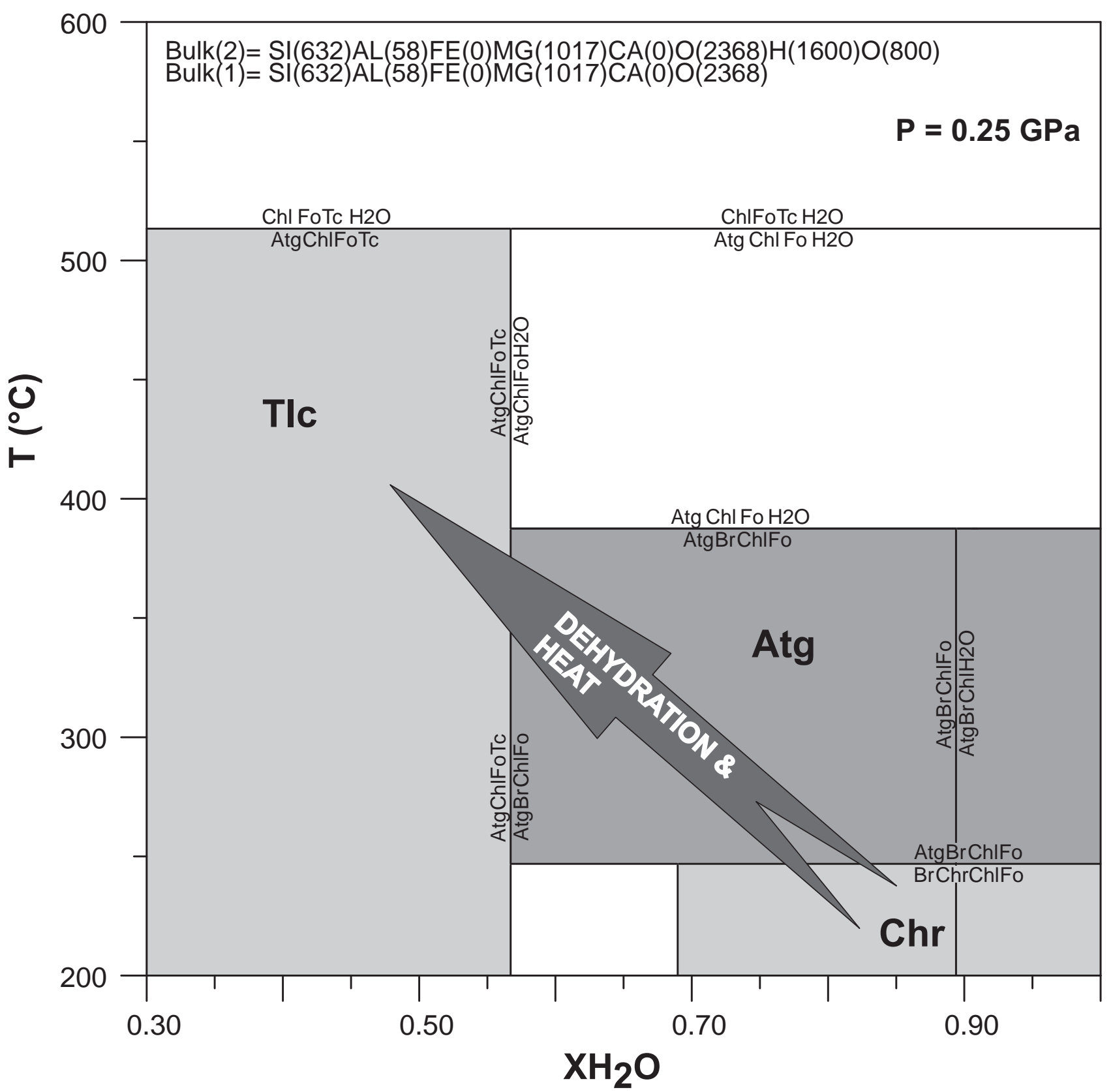

Fig. 14 Equilibrium paragenesis of antigorite-talc-bearing serpentinites in the $P-T$ diagram. For details, see the text.

\subsubsection{Static hydration stage}

Some GS samples preserve mineral phases from the early partial hydration of the ultramafic protolith. The textural studies are consistent with the modelling results, which demonstrate that antigorite and tremolite formed from enstatite due to retrograde metamorphism at $c .630-680^{\circ} \mathrm{C}$. The likely source of Ca to form tremolite was Ca-pyroxene from the protolith. The typical serpentinites in the GS and HS are characterized by mutually comparable metamorphic parageneses. As a result of low-T hydration, polygonally-textured mesh serpentinite (lizardite and chrysotile) developed in the olivine-bearing domains, while pyroxene-amphibole domains were transformed into bastites (lizardite and chrysotile). The pseudomorphous texture had to form in a stress-free environment, under static conditions, at c. $230-250^{\circ} \mathrm{C}$.

\subsubsection{Deformation stage}

The effects of the pseudomorphous texture deformation can be observed in both serpentinized ultramafic bodies. Isometric cells were disaggregated, and transition-textured serpentinite developed with the coeval appearance 
of steep foliation $\left(\mathrm{S}_{1}\right)$. Penetrative $\mathrm{S}_{1}$ foliation is typical of all lithologies in both bodies.

Antigorite \pm talc \pm chlorite 2 paragenesis appears locally in the serpentinite samples along $\mathrm{S}_{2}$ planes that intersect the $\mathrm{S}_{1}$ foliation. The thermometric modelling by THERIAK-Domino shows that this paragenesis is stable at $T>250^{\circ} \mathrm{C}$, so the main serpentinization event had to be followed by reheating. Serpentinite mylonite also developed in places in connection with $\mathrm{S}_{2}$ in the GS bastites, while mesh-textured serpentinite defines the sheared clasts in the HS.

\subsubsection{Post-metamorphic alteration stage}

Based on its textural position, the formation of the common $\mathrm{Mg}$-carbonate postdated the serpentinization. Its formation was probably related to a $\mathrm{CO}_{2}$ metasomatism, as proven by the appearance of post-kinematic carbonate grains and their aggregates.

\subsection{Geodynamic interpretation}

The identical evolution stages inferred for both the GS and the HS can be interpreted in the following geodynamic framework.

1) The protolith, a tectonized mantle peridotite, likely formed structurally the lowermost unit of the ophiolite series. High-T, ductile deformation probably represented the earliest $\left(\mathrm{D}_{0}\right)$ deformation stage of the mantle peridotites during unroofing.

2) During ocean-floor metamorphism, the harzburgite-bearing upper mantle became slightly hydrated. As spreading continued, it diverged from the hot, axial part of the ridge, so the temperature gradually decreased away from the spreading centre. This evolution is confirmed by the preserved retrograde mineral succession in the GS. Experiments of Demartin et al. $(2002,2004)$ proved that micro-cracks usually form due to thermal contraction during the uplift of a mantle diapir along ocean ridges. These microfractures developed at a depth of 3-8 km under the seafloor $\left(T: 300-350{ }^{\circ} \mathrm{C}\right.$, Andreani et al. 2007) and may have had a significant role in ensuring fluid flow into the deep oceanic lithosphere. As metamorphism continued, secondary minerals became predominant until they completely consumed the primary phases. Because olivine and pyroxene relics are still present in the GS, only partial hydration could occur in the higher temperature regime, creating anthophyllite, tremolite and talc. As the temperature decreased, the hydration became more and more intense, resulting in the formation of a typical serpentinite. Escartín et al. (2004) proved experimentally that serpentinite has extremely low hydraulic conductivity and negligible communicating porosity. Because the GS was only partially hydrated, it was probably located farther from the fluid source, that is, deeper in the oceanic lithosphere than the HS. Such a spatial relationship is also proven by the fact that the protolith of the GS is related to a more depleted oceanic crust (harzburgite), while olivine websterite and orthopyroxenite are more common in the HS based on the Streckeisen diagram (Fig. 10).

3) Following the main ocean-floor metamorphic event, both the GS and HS bodies deformed at conditions close to isothermal. The pervasive $S_{1}$ foliation probably developed along a detachment shear zone. Along these excellent fluid flow paths, amphibole and chlorite usually appeared, defining subsequent zones with different deformation states and mineralogy (O'Hanley and Offler 1992; O'Hanley 1996). The pervasively serpentinized, foliated serpentinite was presumably located directly at the shear zone; the bastite-bearing serpentinite formed farther away, while the ultramafic-bearing serpentinite defined the outermost zone.

4) The presence of antigorite + talc paragenesis in the serpentinites that were metamorphosed and deformed during ocean-floor metamorphism indicates an overprint due to heating and coeval dehydration. This simultaneous deformation caused pervasive $\mathrm{S}_{2}$ foliation and even mylonitisation in places, clearly suggesting the role of subduction in the late evolution of the oceanic lithosphere (Hermann et al. 2000). Based on the results of the thermometric modelling, neither GS nor HS exceeded $500^{\circ} \mathrm{C}$ during this subduction event, which agrees with the interpretation of Ulmer and Trommsdorff (1995).

\subsection{Regional correlation}

The earlier correlations have revealed a number of similarities in Variscan evolution of the area studied (SW Tisia) and the Bohemian Massif. R. Varga et al. (2003) pointed to similarities in the petrographic, sedimentological and geochemical features of the Carboniferous Téseny Fm. in SW Tisia and the formations in the Upper Silesian coal basin and Cracow Sandstone. These authors also confirmed the uniform geochemical nature of the pyroclasts in SW Tisia and the calc-alkaline volcanic rocks in the Intra Sudetic Basin. Based on detailed petrological studies of the Mórágy granite, the country rock of the HS, Buda (1985) and Buda et al. (1999) showed a close genetic relationship with the granitoid rocks of the Bohemian Massif. Klötzli et al. (1999) described the granitoids in SW Tisia as a $\mathrm{K}-\mathrm{Mg}$-rich durbachitic plutonic series, similar to those found in the central and eastern parts of the Moldanubian Zone (Janoušek and Holub 2007; von Raumer et al. 2014). 
The petrological data for the two serpentinite bodies may present additional information about the paleogeographic position of the SW Tisia crystalline basement. Their structural setting, protolith types, and tectonometamorphic history are all rather similar to those of some Sudetic ophiolites.

The Góry Sowie Massif in the West Sudetes represents likely a fragment detached from the Bohemian Massif (Cymerman 1990; Dubińska and Gunia 1997; Faryad and Kachlík 2013). It consists essentially of different gneiss varieties, although contains numerous small ultrabasic (serpentinized to a variable degree) and metabasic rock bodies (e.g. Cymerman 1990). Larger mafic-ultramafic bodies, known as the Central Sudetic Ophiolite, crop out along the northern (Ślęża Ophiolite), eastern (Szklary and Braszowice-Brzeźnica serpentinite massifs) and southwestern (Nowa Ruda Gabbro-Diabase Massif) rims of the Góry Sowie Massif (Dubińska and Gunia 1997; Gunia 2000; Mazur et al. 2006; Kryza and Pin 2010). Similar to OS that is wedged in the Mecsekalja Shear Zone, Braszowice-Brzeźnica and Szklary massifs are incorporated into the Niemcza Shear Zone (Dubińska and Gunia 1997; Gunia 2000; Kryza and Pin 2010).

In all these localities, similar to the GS and HS, the proportion of unaltered ultramafic rocks is negligible, while entirely serpentinized bodies are frequent. The protolith was mainly harzburgite with subordinate orthopyroxenite, olivine websterite and lherzolite (Dubińska and Gunia 1997). The initial serpentinization was a low-grade metamorphic event, which probably took place in an ocean-floor environment and resulted in pseudomorphous lizardite and chrysotile textures. Afterwards, the primary serpentinite recrystallized into an antigorite and talc-bearing non-pseudomorphous-textured variety in the Jordanów-Gogołów and Braszowice-Brzeźnica massifs. In the Szklary Massif, the ultramafic rocks belong to tectonite peridotites at the base of the ophiolite sequence (Gunia 2000).

Coarse-grained biotite gneiss predominates in the central part of the Góry Sowie, in which serpentinites are bordered by large individual blocks and form small elongated bodies similar to those typical in SW Tisia (Gunia and Szczepański 1994). The serpentinites in this area exhibit identical textural features (pseudomorphous, transitional, and mylonitic) and evolution stages to GS and HS. In addition, the olivine composition of ultramafic relics $\left(\mathrm{Fo}_{92}\right)$ is similar to that of the protolith to the GS. According to the relevant models, the ultramafic rocks in the Góry Sowie block were serpentinized on seafloor during spreading and then consumed in a subduction zone. These models emphasize that only those fragments that were thrust onto the mantle wedge and so avoided deep subduction could be preserved. An identical palaeotec- tonic interpretation of the serpentinites in SW Tisia was given by Balla (1981).

The geological position of the Jordanów-Gogołów serpentinite massif (lower part of the Ślęża Ophiolite, Majerowicz 1979) and the composition of the serpentinized peridotites (Dubińska et al. 1995) are similar to those of the HS. Western contact of the Jordanów-Gogołów serpentinite massif was intruded by the Variscan Strzegom-Sobótka granite (e.g. Kryza and Pin 2010) and southeastern parts of the same serpentinite are cut by Variscan granitoid dykes (Kryza 2011). Unfortunately the granite surrounding the HS is highly cataclastic (Fülöp 1994; Rónaky 1996) and thus the nature of the contact is unclear. Concerning aplitic dykes $(340 \pm 34$ Ma: Svingor and Kovách 1981), both the GS and HS resemble the Central Sudetic ophiolites, where dykes of the Carboniferous age frequently intrude the serpentinite masses. Small leucocratic bodies and veins in the Gogołów-Jordanów serpentinite massif relate to Variscan granites (Majerowicz 1984; Majerowicz and Pin 1989); the magmatic crystallization age of the granite dyke in the serpentinite at Jordanów (337 \pm 4 Ma: Kryza 2011) fits well with the age of the surrounding granitoid rocks, such as the c. $340 \mathrm{Ma}$ Niemcza granite (Oliver et al. 1993; Pietranik et al. 2013).

The subsolidus recrystallization temperature of the metamorphic peridotites in the Sudetes calculated by the Ol-spinel thermometer was $620-715^{\circ} \mathrm{C}$ (Dubińska and Gunia 1997). Using the method of Fabriès (1979), the temperature was estimated at $666-749^{\circ} \mathrm{C}$ (Szklary), $618-697{ }^{\circ} \mathrm{C}$ (Jordanów-Gogołów) and $630-650^{\circ} \mathrm{C}$ (Braszowice-Brzeźnica) (Gunia 2000). In the GS, this temperature is estimated to be $618-693^{\circ} \mathrm{C}$ (Kovács et al. 2009) based on both thermometers calibrated by Fabriès (1979) and Ballhaus et al. (1991).

Similarly to the Ślęża Ophiolite (Kryza and Pin 2010), a whole ophiolite sequence can be found inside the Rehberg Complex in the southern part of the Bohemian Massif, from mantle tectonites and sheeted dykes to basaltic-rhyolitic volcanic series and abyssal sediments. This sequence probably formed in a suprasubduction (island-arc or back-arc basin) environment (Höck et al. 1997).

Concerning the main evolutionary events, serpentinite bodies in the SW Tisia resemble the numerous ophiolites rimming the Góry Sowie in West Sudetes. This confirms the previous ideas about the related Variscan history of the Sudetes and Tisia blocks. More detailed petrological studies of the serpentinite bodies and the neighbouring intrusive and metamorphic rocks would help in better understanding the palaeogeographic position and geodynamic evolution of the SW Tisia in the framework of the Variscan Europe. 


\section{Conclusions}

The Gyód (GS) and Helesfa (HS) are isolated serpentinized spinel peridotite bodies that were tectonically displaced from the upper mantle into the crust, i.e., they are classified as Alpine-type ultramafic rocks (Coleman 1977). The structural relationship with the adjacent rocks is unknown, although the $\mathrm{He}-2$ borehole penetrated the granite/serpentinite contact. Both bodies represent mantle tectonites probably derived from the base of a dismembered ophiolite sequence; however, in this part of Tisia Mega Unit, the higher sequences are unknown. The protolith to both the GS and HS was dominantly harzburgite, whereas olivine websterite and orthopyroxenite were subordinate.

While the HS is completely serpentinized, relict mineral assemblage of the protolith is preserved in the GS. The hydration of the original ultramafic body started at $\sim 650^{\circ} \mathrm{C}$, when tremolite \pm anthophyllite \pm talc replaced enstatite. Serpentinization took place at $230-250^{\circ} \mathrm{C}$ under static conditions; accordingly, lizardite, chrysotile, secondary magnetite and $\mathrm{Mg}$-chlorite formed, exhibiting a pseudomorphous texture.

This serpentinization event was followed by pervasive deformation, resulting in a $\mathrm{S}_{1}$ foliation in the meshtextured serpentinites. It was probably due to displacement along detachment shear zones and transform faults (Boschi et al. 2006). Antigorite and talc characterize the $\mathrm{S}_{2}$ foliation and mylonite zones that crosscut the $\mathrm{S}_{1}$ foliation. This paragenesis formed by dehydration of normal serpentinite during reheating at $250-500{ }^{\circ} \mathrm{C}$, probably due to the subduction of the oceanic slab. Taken together, the protolith and the metamorphic with structural evolution of the GS and HS bodies were mutually comparable, suggesting that they developed along the same evolution path and, thus, represent fragments of the same ultramafic complex.

Acknowledgements. The authors thank Elżbieta Dubińska and Piotr Gunia for their constructive comments in the correlation between the Lower Silesian ophiolites and the Tisia serpentinites and also the reviewers, V. Kachlík and M. Putiš, as well as editors E. Jelínek and V. Janoušek, are deeply appreciated for their critical observations and corrective helps.

\section{References}

Andreani M, Mével C, Boullier AM, Escartín J (2007) Dynamic control on serpentine crystallization in veins: constraints on hydration processes in oceanic peridotites. Geochem Geophys Geosyst, doi: 10.1029/2006GC001373
Árkai P (1984) Polymetamorphism of the crystalline basement of the Somogy-Dráva Basin (southwestern Transdanubia, Hungary). Acta Mineral-Petrogr (Szeged) 26: $129-153$

Árva-Sós E, Balogh K (1979) Study of the granites of the Mecsek Mountains and metamorphic rocks in their surrounding by K-Ar method. Földt Kut 22: 33-36 (in Hungarian)

Balla Z (1981) Plate tectonics interpretation of South Transdanubia ultramafics. Acta Mineral-Petrogr (Szeged) 25: $3-24$

Balla Z (1983) Plate tectonics interpretation of South Transdanubian ultramafics. Földt Közl 113: 39-56 (in Hungarian)

Balla Z (1985) Pre-Upper Carboniferous mafic and ultramafic rocks in Hungary. In: Dobretsov NL (ed) Riphean-Lower Carboniferous Ophiolites of Northern Eurasia. Nauka, Novosibirsk, pp 136-148 (in Russian)

Ballhaus C, Berry RF, Green DH (1991) High pressure experimental calibration of the olivine-orthopyroxene-spinel oxygen geobarometer: implications for the oxidation state of the upper mantle. Contrib Mineral Petrol 107: 27-40

Balogh K, Árva-Sós E, Buda G (1983) Chronology of granitoid and metamorphic rocks of Transdanubia (Hungary). Anuarul Institutului de Geologie şi Geofizică 61: 359-364

Bashir E, Naseem S, Kaleem M, Khan Y, Hamza S (2012) Study of serpentinized ultramafic rocks of Bela ophiolite, Balochistan, Pakistan. J Geogr Geol 4: 79-89

BERMAN RG (1988) Internally-consistent thermodynamic data for minerals in the system $\mathrm{Na}_{2} \mathrm{O}-\mathrm{K}_{2} \mathrm{O}-\mathrm{CaO}-\mathrm{MgO}$ $\mathrm{FeO}-\mathrm{Fe}_{2} \mathrm{O}_{3}-\mathrm{Al}_{2} \mathrm{O}_{3}-\mathrm{SiO}_{2}-\mathrm{TiO}_{2}-\mathrm{H}_{2} \mathrm{O}-\mathrm{CO}_{2}$. J Petrol 29: 445-522

Boillot G, FÉraud GMR, Girardeau J (1989) Undercrusting by serpentinite beneath rifted margins. Nature 341 : 523-525

Boillot G, Beslier M-O, Comas M (1992) Seismic image of undercrusted serpentinite beneath a rifted margin. Terra Nova 4: 25-33

Bonatti E, Michael PJ (1989) Mantle peridotite from continental rifts to ocean basins to subduction zones. Earth Planet Sci Lett 91: 297-311

Boschi C, Früh-Green GL, Delacour A, Karsin J A, Kelley DS (2006) Mass transfer and fluid flow during detachment faulting and development of an oceanic core complex, Atlantis Massif (MAR 30N). Geochem Geophys Geosyst, doi: 10.1029/2005GC010174

Brown G E (1980) Olivine and silicate spinels. In: RibBE PH (ed) Orthosilicates. Mineralogical Society of America Reviews in Mineralogy 5: pp 275-381

Buda Gy (1981) Genesis of the Hungarian granitoid rocks. Acta Geol Hung 24: 309-318 
BudA Gy (1985) The genesis of the Hungarian, West Carpathian, Central Bohemian Variscan collision-type granitoids. Unpublished Dissertation, Eötvös Loránd University, Budapest, pp 1-148 (in Hungarian)

Buda Gy, Lovas Gy, Klötzli U, Cousen BI (1999) Variscan granitoids of the Mórágy Hills (South Hungary). Beih Eur J Mineral 11: 21-32

Buda Gy, Koller F, Ulrych J (2004) Petrochemistry of Variscan granitoids of Central Europe: correlation of Variscan granitoids of the Tisia and Pelsonia terranes with granitoids of the Moldanubicum, Western Carpathian and Southern Alps. A review: part I. Acta Geol Hung 47: $17-138$

Cannat M, Mevel C, Maia M, Deplus C, Durand C, Gente P, Agrinier P, Belarouchi A, Dubuisson G, Humler E, Reynolds J (1995) Thin crust, ultramafic exposures, and rugged faulting patterns at the Mid Atlantic Ridge $\left(22^{\circ}-24^{\circ} \mathrm{N}\right)$. Geology 23: 49-52

Coleman RG (1977) Ophiolites. Springer-Verlag, Berlin, Heidelberg, New York, pp 1-229

Csontos L, Nagymarosy A, Horváth F, Kovác M (1992) Tertiary evolution of the intra-Carpathian areas: a model. Tectonophysics 208: 221-241

Cymerman Z (1990) Structural evolution of the Sowie Góry unit in the area of northern part of the Bielawa Hills, Sudetes Mts. Geo. Sudet 24: 191-283

de CAPITANI C (1994) Gleichgewichts-Phasendiagramme: Theorie und Software. Beih Eur J Mineral 6: 48

DE CAPITANI C, BRown TH (1987) The computation of chemical equilibrium in complex systems containing non-ideal solutions. Geochim Cosmochim Acta 51: 2639-2652

de Capitani C, Petrakakis K (2010) The computation of equilibrium assemblage diagrams with Theriak/Domino software. Amer Miner 95: 1006-1016

Demartin B, HiRth G (2002) Experimental constraints on thermal cracking of peridotite at slow spreading ridges: implications for fluid flow. InterRidge Theoretical Institute: Thermal regime of ocean ridges and dynamics of hydrothermal circulation. Abstracts Volume, Pavia/ Sestri Levante, Italy

Demartin B, Hirth G, Evans B (2004) Experimental constraints on thermal cracking of peridotites at oceanic spreading centres. In: GERMAN CR, LIN J, PARSON LM (eds) Mid-Ocean Ridges: Hydrothermal Interactions Between the Lithosphere and Oceans. Geophysical Monograph Series 148: pp 167-185

Dick HJB, Bullen T (1984) Chromian spinel as a petrogenetic indicator in abyssal and alpine-type peridotites and spatially associated lavas. Contrib Mineral Petrol 86: $54-76$

DROOP GTR (1987) A general equation estimating $\mathrm{Fe}^{3+}$ concentrations in ferromagnesian silicates and oxides from microprobe analyses, using stoichiometric criteria. Miner Mag 51: 431-435
DubińSKa E, Gunia P (1997) The Sudetic ophiolite: current view on its geodynamic model. Geol Q 41: 1-20

Dubińska E, Jelitto J, KozŁowski A (1995) Origin and evolution of the granite/serpentine reaction zones at Wiry, Lower Silesia. Acta Geol Polonica 45: 41-82

Dungan MA (1979a) A microprobe study of antigorite and some serpentine pseudomorphs. Canad Mineral 17: $771-784$

DunGan MA (1979b) Bastite pseudomorphs after orthopyroxene, clinopyroxene and tremolite. Canad Mineral 17: 729-740

ERDÉLYI J (1974) Mineral investigations of Hungarian serpentinites. Földt Kut 17: 97-100 (in Hungarian)

Escartín J, Hirth G, Evans B (2004) Permeability of serpentinite and the rheology of talc localization of deformation and subduction process. Geophys Res Abstr 6: 07599

FARYAD SW, KACHLí́ V (2013) New evidence of blueschist facies rocks and their geotectonic implication for Variscan suture(s) in the Bohemian Massif. J Metamorph Geol 31: 63-82

FABRIÈS J (1979) Spinel-olivine geothermometry in peridotites from ultramafic complexes. Contrib Mineral Petrol 69: 329-336

Francis G H (1956) The serpentine mass in Glen Urquhart, Inverness-shire, Scotland. Amer J Sci 254: 201-226

FüLÖP J (1994) Geology of Hungary Paleozoic II. Akadémiai Kiadó, Budapest, pp 1-455

Géresi Gy, Elek I, Baranyai I (1971) Complex aerospectrometric and magnetic investigations in Hungary. Magy Geofiz XI: 41-51 (in Hungarian)

Ghoneim MF (1978) Petrogenesis of the Eugeosynclinal Metamorphites and Related Rocks, Mecsek Mountains, Hungary. Unpublished PhD. Thesis, Hungarian Academy of Sciences, Budapest, pp 1-157

Ghoneim MAE, Ravasz-Baranyai L (1969) Petrographic study of the crystalline basement rocks, Mecsek Mts., Hungary. Acta Geol Hung 13: 191-219

Ghoneim MF, Szederkényi T (1979) Petrological review of the Ófalu serpentinite, Mecsek Mountains, Hungary. Acta Mineral-Petrogr (Szeged) 24: 5-18

GRANT JA (1986) The isocon diagram - a simple solution to Gresens' equation for metasomatic alteration. Econ Geol 81: 1976-1982

Gresens RL (1967) Composition-volume relationships of metasomatism. Chem Geol 2: 47-65

Groppo C, Rinaudo C, Cairo S, Gastaldi D, Compagnoni R (2006) Micro-Raman spectroscopy for a quick and reliable identification of serpentine minerals from ultramafics. Eur J Mineral 18: 319-329

GuniA P (2000) The petrology and geochemistry of mantlederived basic and ultrabasic rocks from the Szklary Massif in the Fore-Sudetic Block (SW Poland). Geol Sudetica 33: 71-83 
Gunia P, SzCZEPAŃski J (1994) Metamorphic assemblages in ultramafic rocks from Central part of Sowie Mts gneisses (Lower Silesia, Poland). B Pol Acad Sci-Earth 42: 89-98

Gunia P, ZióŁKowska-Kozdrój M, Kozdrój W (1998) New geochemistry data of ultrabasic rocks from eastern surroundings of the Karkonosze granite intrusion (Sudetes, SW Poland). B Pol Acad Sci-Earth 46: 94-108

HaAs J, Kovács S, Krystyn L, Lein R (1995) Significance of Late Permian-Triassic facies zones in terrane reconstructions in the Alpine-North Pannonian domain. Tectonophysics 242: 19-40

HAIDINGER W (1845) Naturwissenschaftliche Abhandlungen. Vols $1-4$, Wien

Hermann J, Müntener O, Scambelluri M (2000) The importance of serpentinite mylonites for subduction and exhumation of oceanic crust. Tectonophysics 327: 225-238

Horváth P, Kovács G, Szakmány Gy (2003) Eclogite and garnetiferous amphibolite gravels from Miocene conglomerates: new results for the Variscan metamorphic evolution of the Tisza Unit (Pannonian Basin, Hungary). Geol Carpath 54: 1-12

Höck V, Montag O, Leichmann J (1997) Ophiolite remnants at the eastern margin of the Bohemian Massif and their bearing on the tectonic evolution. Mineral Petrol 60: 267-287

JANOUŠEK V, HoLuB FV (2007) The causal link between HPHT metamorphism and ultrapotassic magmatism in collisional orogens: case study from the Moldanubian Zone of the Bohemian Massif. Proc Geol Assoc 118: 75-86

JANTSKY B (1979) Geology of granitized crystalline basement in Mecsek Mts. MÁFI Évkönyv 60: pp 1-365 (in Hungarian)

Jaques AL, Chappell BW (1980) Petrology and trace element geochemistry of the Papuan Ultramafic Belt. Contrib Mineral Petrol 75: 55-70

Kloprogge JT, Frost RL, Rintoul L (1999) Single crystal Raman microscopic study of the asbestos mineral chrysotile. Phys Chem Chem Phys 1: 2559-2564

Klötzli US, Buda Gy, Koller F (1999) Geochronological evidence for the derivation of the Mecsek Mountains, South Hungary from Variscan Central Europe. Beih Eur J Mineral 11: 126

KLÖTZli US, Buda Gy, SkiöLd T (2004) Zircon typology, geochronology and whole rock $\mathrm{Sr}-\mathrm{Nd}$ isotope systematics of the Mecsek Mountain granitoids in the Tisia Terrane (Hungary). Mineral Petrol 81: 113-134

Konrád Gy, Sebe K, Halász A, Halmai Á (2010) Geologic evolution of SE Transdanubia - recent analogies. Földr Közl 134: 251-265 (in Hungarian)

KovÁcs G (2000) Petrographical characteristics of the Gyód Serpentinite Body, south-eastern Transdanubia. Acta Mineral-Petrogr (Szeged) XLI: 79-91

Kovács G, Raucsik B, Horváth P (2003) Minerals of Gyód serpentinite body, Hungary. Acta Mineral-Petrogr (Szeged), Abstract series 1: 54
Kovács G, M. Tóth T, Schubert F (2009) Petrology of the Gyód serpentinite. In: M. То́тн T (ed) Magmatic and Metamorphic Rocks in the Tisia Unit. GeoLitera, Szeged, pp 65-80

KRETZ R (1983) Symbols for rock-forming minerals. Amer Miner 68: 277-279

KRYZA R (2011) Early Carboniferous ( 337 Ma) granite intrusion in Devonian ( 400 Ma) ophiolite of the CentralEuropean Variscides. Geol Q 55: 213-222

Kryza R, PIN C (2010) The Central-Sudetic ophiolites (SW Poland): petrogenetic issues, geochronology and palaeotectonic implications. Gondwana Res 17: 292-305

LAGABRIELlE Y, CANNAT M (1990) Alpine Jurassic ophiolites resemble the modern central Atlantic basement. Geology 18: $319-322$

Lemoine M, Tricart P, Boillot G (1987) Ultramafic and gabbroic ocean floor of the Ligurian Tethys (Alps, Corsica, Apennines): in search of a genetic model. Geology 15: $622-625$

M. То́тн T (2014) Geochemistry of the Görcsöny Ridge amphibolites (Tiszia Unit, SW Hungary) and its geodynamic consequences. Geol Croatica 67: 17-32

Majerowicz A (1979) The Ślęża Mt. group and ophiolite problem. Vol. of Sci. Session in Nowa Ruda, 9-10 Wrocław University (in Polish)

Majerowicz A (1984) Petrography and origin of rodingitic rocks from serpentinites of Ślęża ophiolitic sequence. Geol Sudetica 18: 109-132 (in Polish)

Majerowicz A, PIN C (1989) Recent progress in petrologic study of the Ślęża Mt. ophiolite complex, Lower and Upper Paleozoic metabasites and ophiolites of the Polish Sudetes. In: Multilateral Cooperation of Academies of Sciences of Socialist Countries, Guidebook of Excursion in Poland. University of Wrocław, Wrocław, pp 34-72

MÁrton E (2000) The Tisza Megatectonic Unit in the light of paleomagnetic data. Acta Geol Hung 43: 329-343

Mazur S, Aleksandrowski P, Kryza R, Oberc-Dziedzic $\mathrm{T}$ (2006) The Variscan Orogen in Poland. Geol Q 50: 89-118

Medaris G, Wang H, Jelínek E, Mihaljevič M, Jakeš P (2005) Characteristics and origins of diverse Variscan peridotites in the Gföhl nappe, Bohemian Massif, Czech Republic. Lithos 82: 1-23

Melcher F, Meisel T, Puhl T, Koller F (2002) Petrogenesis and geotectonic setting of ultramafic rocks in the Eastern Alps: constraints from geochemistry. Lithos 65: 69-112

Mercier JCC, Nicolas A (1975) Textures and fabrics of upper mantle peridotites as illustrated by xenoliths from basalts. J Petrol 16: 454-487

Monnier C, Girardeau J, Pubbellier M, Polvé M, Permana H, Bellon H (1999) Petrology and geochemistry of the Cyclops ophiolites (Irian Jaya, East Indonesia): consequences for the Cenozoic evolution of the north Australian margin. Mineral Petrol 65: 1-28 
NAgy Á, M. Tóth T (2009) Relict textural elements in the garnetiferous gneiss unit of the Görcsöny Unit. In: M. То́тн T (ed) Magmatic and Metamorphic Formations in Tisia Unit. GeoLitera, Szeged, pp 65-79

NiIDA K (1997) Mineralogy of MARK peridotites: replacement through magma channelling examined from hole 920D, MARK area. In: Karson JA, Cannat M, Miller DJ, Elthon D (eds) Proceedings of the Ocean Drilling Program, Scientific Results 53: 265-275

O'HANLEY DS (1991) Fault-related phenomena associated with hydration and serpentine recrystallization during serpentinization. Canad Mineral 29: 21-35

O'HANLey DS (1996) Serpentinites: Records of Tectonic and Petrological History. Oxford University Press, New York and Oxford, pp 1-277

O'Hanley DS, Offler R (1992) Characterization of multiple serpentinization, Woodsreef, New South Wales. Canad Miner 30: 1113-1126

Oliver GJH, Corfu F, Krogh TE (1993) U-Pb ages from SW Poland: evidence for a Caledonian suture zone between Baltica and Gondwana. J Geol Soc, London 150: 355-369

PAPP G (1989) Investigations on serpentine minerals mostly in Hungarian occurrences. Unpublished Ph.D. Thesis, Eötvös Loránd University, Budapest, pp 1-148 (in Hungarian)

Parkinson IJ, Pearce JA (1998) Peridotites from the IzuBonin-Mariana Forearc (ODP Leg 125): evidence for mantle melting and mantle-melt interaction in a suprasubduction zone setting. J Petrol 39: 1577-1618

Pearce JA, Baker PF, Edwards SJ, Parkinson IJ, Leat PT (2000) Geochemistry and tectonic significance of peridotites from the South Sandwich arc-basin system, South Atlantic. Contrib Mineral Petrol 139: 36-53

Piccardo GB, Cimmino F, Messiga B (1980) Antigorite serpentinites and rodingites from the Voltri Massif: some petrological evidence for their evolutive history. Ofioliti 5: 111-114

Pietranik A, Storey C, Kierczak J (2013) The Niemcza diorites and monzodiorites (Sudetes, SW Poland): a record of changing geotectonic setting at ca. $340 \mathrm{Ma}$. Geol Q 57: 325-334

R. Varga A, Szakmány Gy, Máthé Z, Józsa S (2003) Petrology and geochemistry of Upper Carboniferous siliciclastic rocks (Téseny Sandstone Formation) from the Slavonian-Drava Unit (Tisza Megaunit, S Hungary) - summarized results. Acta Geol Hung 46: 95-113

Ravasz-BARANYAi L (1969) Eclogite of the Mecsek Mountains, Hungary. Acta Geol Hung 13: 315-322

Rinaudo C, Gastaldi D, Belluso E (2003) Characterization of chrysotile, antigorite and lizardite by FT-Raman spectroscopy. Canad Mineral 41: 883-890

RÓNAKY L (1996) Exploration history of granite outcrops in the W-Mecsek Mts. Földt Közl 126: 313-317 (in Hungarian)
Sobolev N D (1952) Ultramafic Rocks of the Greater Caucasus. Gosgeolizdat, Moscow, pp 1-240 (in Russian)

StReCKeISEN A (1976) To each plutonic rock its proper name. Earth Sci Rev 12: 1-33

Svingor É, Kovích Á (1981) Rb-Sr isotopic studies on granodioritic rocks from the Mecsek Mountains, Hungary. Acta Geol Hung 24: 295-307

SZEDERKÉNYI T (1974) Paleozoic magmatism and tectogenesis in South-East Transdanubia. Acta Geol Hung 18: 305-313

SZEDERKÉNYI T (1976a) Barrow-type metamorphism in the crystalline basement of Southeast Transdanubia. Acta Geol Hung 13: 27-34

SZEDERKÉNYi T (1976b) Cr, Ni, As, Pt, Os, Ir and Au contents of ultramafic rocks and their derivatives in the South Transdanubia. Hungarian Geological Society, South Transdanubia Regional Branch, Pécs, pp 1-77 (in Hungarian)

SZEDERKÉNYi T (1977) Geological evolution of South Transdanubia (Hungary) in Paleozoic time. Acta MineralPetrogr (Szeged) 23: 3-14

SZEDERKÉNYI T (1979) Origin of amphibolites and metavolcanics of crystalline complexes of south Transdanubia, Hungary. Acta Geol Hung 26: 103-136

SZEDERKÉNYI T (1984) Crystalline basement and geological relations of the Great Plain. Unpublished D.Sc. Thesis, MTA Library, Budapest, pp 1-170 (in Hungarian)

SZEDERKÉNYI T (1996) Metamorphic formations and their correlation in the Hungarian part of the Tisza Megaunit (Tisia Composite Terrane). Acta Mineral-Petrogr (Szeged) 37: 143-160

SZEDERKÉNYI T (1998) Lithostratigraphy of South Transdanubia and crystalline basement of Great Hungarian Plain. In: BérCZI I, JÁMBOR Á (eds) Lithostratigraphy of Hungarian Geological Formations. Mol Rt. and MÁFI, Budapest, pp 93-106

SzederkÉNyi T, Grasselly GY (1977) Complex processing of the Precambrian-Paleozoic geologic base sections in Mecsek Mts. Unpublished Report, Hungarian Geological Society, Budapest, T6801 pp 1-108 (in Hungarian)

Takahashi E, Uto K, Schilling J-G (1987) Primary magma compositions and $\mathrm{Mg} / \mathrm{Fe}$ ratios of their mantle residues along Mid Atlantic Ridge $29^{\circ} \mathrm{N}$ to $73^{\circ} \mathrm{N}$. Tech Rep ISEI, Okayama Univ, Ser A, 9: 1-14

TrommsdorfF V, Evans BW (1974) Alpine metamorphism of peridotitic rocks. Schweiz Mineral Petrogr Mitt 54: 333-352

Ulmer P, Trommsdorff V (1995) Serpentine stability to mantle depths and subduction related magmatism. Science 268: 858-861

von Raumer JF, Finger F, Veselá P, Stampfli GM (2014) Durbachites-Vaugnerites - a geodynamic marker in the central European Variscan orogen. Terra Nova 26: 85-95

WiCKS FJ, WhitTAKer EJW (1977) Serpentine textures and serpentinization. Canad Mineral 15: 459-488 